University of Rhode Island

DigitalCommons@URI

Open Access Master's Theses

1977

\title{
KINGSTON: THE HISTORICAL GEOGRAPHY OF AN ENTREPRENEURIAL VILLAGE
}

Olive B. Higbee

University of Rhode Island

Follow this and additional works at: https://digitalcommons.uri.edu/theses

\section{Recommended Citation}

Higbee, Olive B., "KINGSTON: THE HISTORICAL GEOGRAPHY OF AN ENTREPRENEURIAL VILLAGE"

(1977). Open Access Master's Theses. Paper 1806.

https://digitalcommons.uri.edu/theses/1806

This Thesis is brought to you for free and open access by DigitalCommons@URI. It has been accepted for inclusion in Open Access Master's Theses by an authorized administrator of DigitalCommons@URI. For more information, please contact digitalcommons-group@uri.edu. 
KINGSTON: THE HISTORICAL GEOGRAPHY OF AN ENTREPRENEURIAL VILLAGE

BY

OLIVE B. HIGBEE

A THESIS SUBMITTED IN PARTIAL FULEILIMENT OF THE REQUIREMENTS FOR THE DEGREE OF MASTER OF ARTS

IN

GEOGRAPHY

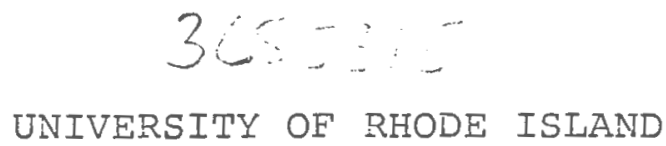




\section{ABSTRACT}

This research study describes the development of Kingston, Rhode Island, and identifies the major factors which have affected this evolution.

The first part of the research deals with the physical characteristics of the Kingston village site. Factors such as topography, bedrock, soil types and hydrology are discussed and mapped. It was found that the site offered early residents an ample water supply and soils that could support agriculture.

The second section of this study is concerned with the historical background of the area as well as Kingston village's evolution from early settlement to its present form. It was found that kingston village was the site of large farms. Local initiative was instrumental in establishing'Kingston as the county seat.

The third section discusses the village's present form, environmental problems and suggestions which might alleviate them. 
The information and maps in this study could aid others, in a practical sense, in their research of small towns or small scale urban development. Planners might also find the study useful as to future development and townspeople might find the study interesting as to their own town's development. 


\section{ACKNOWLEDGEMENTS}

The resources of the following institutions were most helpful in the preparation of this manuscript: the University of Rhode Island, the Rhode Island Historical Scoiety, the Kingston Free Library, and the pettaquamscutt Historical Society.

A number of people were most cooperative in helping me obtain reference materials and documentation used in preparation of this thesis. David Maslyn, Roger Merola, Elizabeth Nye, Anna Prager, Foster Sheldon, and Laurie Ferraco deserve special mention. I also wish to acknowledge the comments of my thesis committee. 
Abstract . . . . . . . . . . . . . . . . . ii Acknowledgements . . . . . . . . . . . . . . iv List of Illustrations . . . . . . . . . ... . vii Chapter

I. INTRODUCTION ................. I

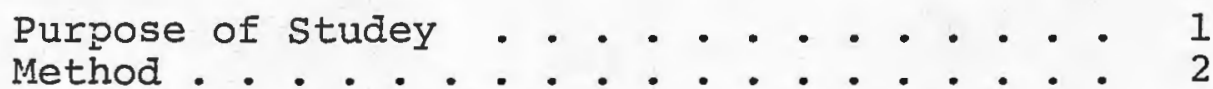

Hypothesis . . . . . . . . . . . 3

Study Area . . . . . . . . . . . . . 3

Literature Review . . . . . . . . 5

II. PHYSICAL CHARACTERISTICS OF KINGSTON AND

VICINITY . . . . . . . . . . . . . . 16

Topography A Site Factor ........ . 16

Bedrock . . . . . . . . . . . 20

Soils . . . . . . . . . . . . 20

Water Supply . . . . . . . . . . 23

III. THE FIRST LAND DIVISIONS . . . . . . . . 26

Pettaquamscutt Purchase . . . . . . 30

Occupation of The Land . . . . . . . . 35

Division of Land At Kingston Site . . . . 37

Cultural Morphology .. . . . . . 40

IV. KINGSTON'S RISE WITHIN THE RHODE ISLAND URBAN HIERARCHY. . . . . . . . . . . . 43

Newport--Primate Center For the Rhode Island Colony . . . . . . . . . . 46

Kingston And The Narragansett Territory

As Hinterland For Newport . . . . . . 48

Kingston Prior to 1750 . . . . . . . . 51

Kingston As Countyseat . . . . . . . . 51

Kingston As An Urban Village . . . . . . 54

Areal Organization And Rank Change . . . 57

Sequent Occupance And Cultural Landscape

(1)

of Kingston 1776 . . . . . . . . . 58 
V. KINGSTON IN AN INDUSTRIAL AGE . . . . . . . .

Rhode Island College of Agriculture And Mechanic Arts ............ . 70 Recent Growth And Land Use Changes . . . 74 The University of Rhode Island . . . . 76 The University And Kingston ....... 83

VI. KINGSTON TODAY . . . . . . . . . . 85

Present Zoning Pattern of Kingston . . . 87

Kingston's Present Land Use Pattern . . . . 91

Kingston's Environmental Problems . . . . . 93

Commuters .............. 94

Parking In The Village :. : . : : 97

Suggested Future Alternatives To Kingston's

Traffic Problem ............

VII. CONCLUSION .............. 105

APPENDICES . . . . . . . . . . . . . . . 116

Appendix A. Map Sources . . . . . . . 117

Appendix B. Questionnaire Data ....... 122

Appendix C. Bibliography. . . . . . . . 125 


\section{LIST OF ILLUSTRATIONS}

Figure

1. KINGSTON STUDY AREA . . . . . . . . . . . 4

2. PHYSIOGRAPHY OF THE KINGSTON SITE . . . . . 17

3. GLACIAL DEPOSITIONS OF THE KINGSTON SITE . . . 19

4. BEDROCK OUTCROPS OF KINGSTON AREA . . . . . . 21

5. SOIL SERIES OF KINGSTON SITE. . . . . . . 22

6. HYDROLOGY OF KINGSTON AREA ......... . 24

7. PETTAQUAMSCUTT PURCHASE TERRITORY . . . . . . 31

8. EARLY ROADS IN NARRAGANSETT TERRITORY . . . . 34

9. KINGSTON SITE: FIRST LAND DIVISION ...... 33

10. KINGSTON VILLAGE IN 1776 . . . . . . . 55

11. KINGSTON VILLAGE IN 1833 . . . . . . . . 65

12. KINGSTON VILLAGE IN 1895 . . . . . . . 75

13. GROWTH PATTERN OF CENTRAL CAMPUS 1900--1921 . . 78

14. GROWTH PATTERN OF CENTRAL CAMPUS 1921--1940. • 79

15. GROWTH PATTERN OF CENTRAI CAMPUS 1941--1960 • •. 80

16. THE UNIVERSITY OF RHODE ISLAND 1977 . . . . . 81

17. KINGSTON STUDY AREA SECTORS . . . . . . . 86

18. KINGSTON CORE ZONING PATTERN . . . . . . . 88

19. KINGSTON STUDY AREA ZONES ......... 90

20. KINGSTON STUDY LAND USE . . . . . . . . . . 92

21. U.R.I. COMMUTER PATTERN . . . . . . . . 95

22. KINGSTON BY-PASS ALTERNATIVE ROUTES . . . . . . 103 
CHAPTER I

\section{INTRODUCTION}

In recent years many geographers have been researching urban structure and the problems of large cities. Almost every segment of urban life has at one time or another been investigated by universities, government agencies, consultants and private individuals.

Small towns or villages, in this country, have not received as much attention as larger urban areas. However, all the interesting facets of urban growth and change are not confined to large cities. This study which examines the small New England village of Kingston, Rhode Island reveals in the chronicle of its evolution the fact that there are problems common to all human settlements regardless of size. Their solutions, as Kingstonians have demonstrated over time, require the exercise of extraordinary ingenuity and entrepreneurial spirit.

Purpose of the study

The primary purpose of this study was to describe the urban evolution of Kingston, Rhode Island in terms of its physical and historical geography. Spatial relationships were mapped and evaluated. After identifying the characteristics of the physical landscape, the first objective was to determine if these site characteristics 
were primary or secondary in determining the location of Ringston village.

A second objective was concerned with the development of the urban area. Economic, social, political and technological factors were considered in the examination of selectively significant periods in the village's evolution and pattern of diffusion.

The third objective was to examine the village at the present time and highlight its environmental problems. Suggestions as to the village's future are included.

Method

Since the study deals largely with historical geography, data were gathered using techniques of library research. Existing maps, air photos, and other cartographic material were analyzed for their use in the study. Field observations were made as to present land use patterns in the study area. University of Rhode Island commuter patterns were tabulated based on the origin for all undergraduate commuters as listed in the "University of Rhode Island student Directory 1974-75." A special questionnaire was administered to those undergraduate commuters who moved away from their parents' homes to the southern Rhode Island region but did not live in a dormitory. Information was also gathered from local government sources, traffic workshop sessions, interviews with developers and records of recent events such as the meeting of the Town Council and 
civic associations. In the interpretation of the data geographic concepts such as "cultural landscape," "sequent occupance," "areal differentiation," and "central place theory" were used in this thesis. Definitions and discussions of these concepts are found in the Literature Review.

\section{Hypothesis}

It has been hypothesized that Kingston evolved as a result of local initiative more than in response to topography, soil and other natural features such as location or accessibility. Entrepreneurial vision, investment, and the wills of strong personalities were more important than natural resources or location in promoting the growth and character of Kingston.

\section{Study Area}

As shown in Figure $I$ the study area is bounded by the following roads and highways: Route 110, Curtis Corner, Saugatucket, Rose Hill, Stony Fort, Wolf Rocks, and Plains. It was chosen because it encompasses the village of Kingston and its immediate environs including both old and new growth areas. However, the analysis was primarily confined to the village's core and its densest residential neighborhoods.

When this research was undertaken it was hoped that an analysis could be made using census data. However, no figures exist which coincide exactly with the study area 


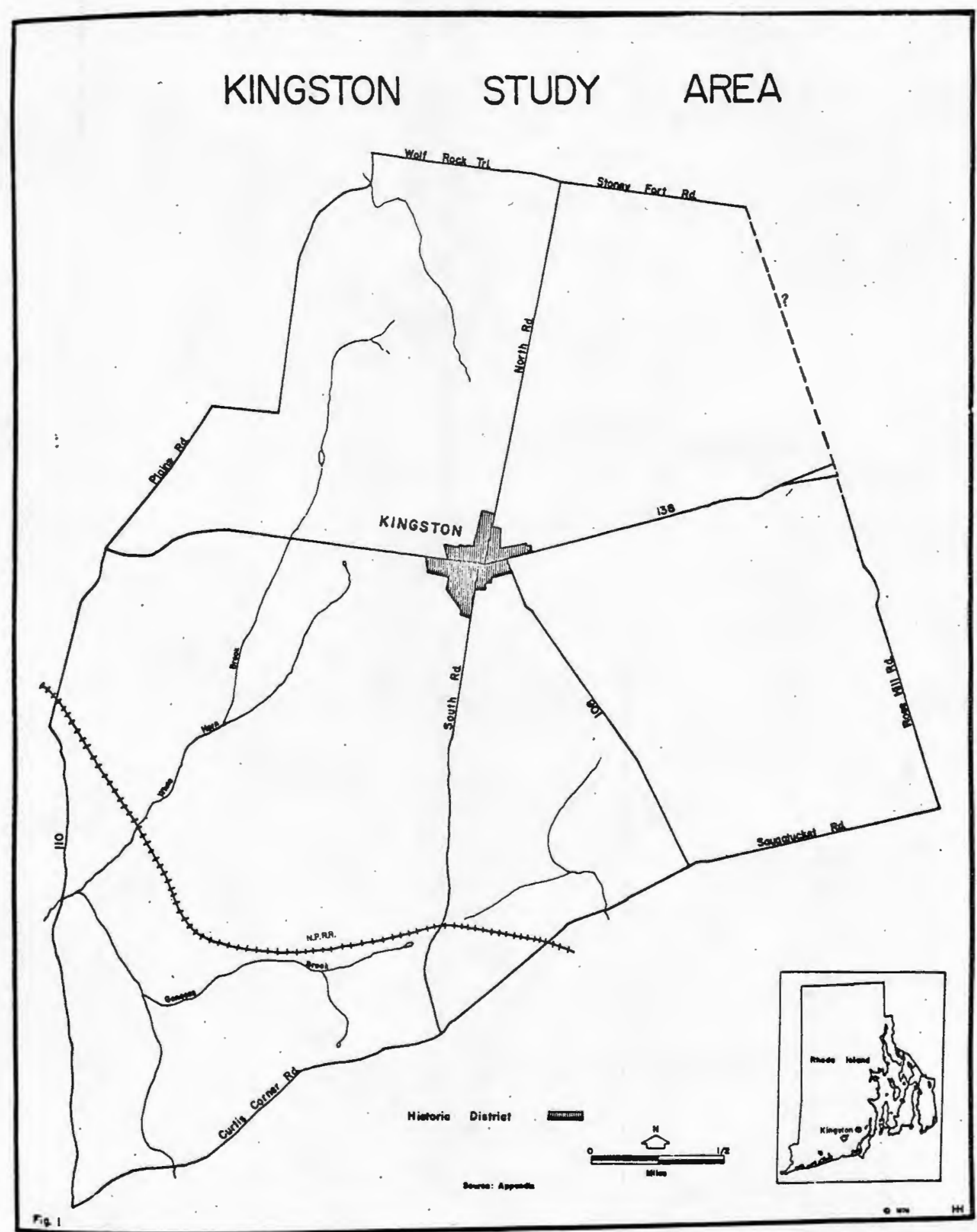


and any juxtaposition of the available figures would be too subjective since they are not comparable.

Literature Review

The sources used in this thesis for historical content were basically of three types. The first were references containing information concerned with the Kingston vicinity. Among those used were: The Early History of Narragansett by Elisha Reynolds Potter ${ }^{l}$, The History of the Episcopal Church in Narragansett Rhode Island by Wilkins updike $^{2}$, reminiscences of the village by local residents, land evidence records, old newspapers, university publications, historical journals, etc.

The second type dealt with background information. Sidney James' Colonial Rhode Island - A History ${ }^{3}$ and John Hutchinson Cady's Rhode Island Boundaries, 1636-1936 ${ }^{4}$ are two examples of books on Rhode Island history which were helpful. A. I. Rowse's The Elizabethans And America ${ }^{5}$ and

$1_{\text {Elisha Reynolds Potter, The Early History of }}$ Narragansett (Providence: Marshall and Brown, 1835).

2 Wilkins Updike, The History of the Episcopal Church in Narragansett, Rhode Island (New York: Henry Onderdonk, 1847).

${ }^{3}$ Sidney James, Colonial Rhode Island - A History (New York: Charles Scribner's \& Sons, 1975).

${ }^{4} J o h n$ Hutchinson Cady, Rhode Island Boundaries, 16351936 (Providence: Rhode Island State Planning Board, 1936).

${ }^{5}$ A. L. Rowse, The Elizabethans And America (New York: Harper \& Bros., 1959). 
Wallace Notestein's The English People on The Eve of Colonization $1609-1630^{6}$ were used as to English culture and background.

Another type of reference material used were old maps and drawings. Maps which contained historical data on the Kingston area were found in the University of Rhode Island Archives, the Kingston Free Library, the Pettaquamscutt Historical Society, the Newport Historical Society and the Rhode Island Historical Society.

The concern of this study has been to evaluate, map, and discuss the factors behind the settlement and the changing patterns of diffusion of the village of Kingston over time. It is a research effort in the field of historical geography. As to historical geography Isaiah Bowman stated,

A man is not educated who lacks a sense of time and place. Where are we in time, where do we live? It was not given to thinking men to change the world overnight--it takes time to change even in small degree at one place. "Place" conditions are therefore limits endeavor whether the place is large or small. Emerson reminds us that we have not been invited to run the universe. Nor did we make the earth or the fullness and diversities thereof. All Life on the earth has been unequal in its parts throughout time, from the beginning. Some streams of migration early and late moved into favorable sites, others into rigorous environments. Cultures arose as the mind of man conceived ideas, codes, language, tools, foods, adornments, and

${ }^{6}$ Wallace Notestein, The English People on the Eve of Colonization 1609-1630 (New York: Harper \& Bros., 1954). 
beliefs. Endless creative interplay between mind and matter ensued, between culture and environment, wherever men were free to choose, reject, or modify. 7

A most helpful book has been that by the historical geographer Ralph Brown's, a classic study in which he describes the impact of geographic location, technology, economics, and society's mores upon settlement of the United states. ${ }^{8}$ He uses maps and old lithographs as descriptive aids. Emrys Jones gives an overview of the concepts and theories of settlement. ${ }^{9}$ He discusses settlements in connection with the region, within hierarchies, and as organic in nature. Jones does not confine his attention to contemporary civilization but also considers pre-industrial settlements. Jean Gottmann takes an historical approach in his study, Megalopolis. ${ }^{10}$ By analyzing the past Gottmann describes the emergence of New York as the dominant city in the East because of its geographic location and economic relationships with its hinterland. Gottmann builds his case over decades of change as the megalopolitan corridor emerges.

7 Isaiah Bowman, "Geographical Interpretation," Geographical Review 39 (1949): p. 367.

${ }^{8}$ Ralph Brown, Historical Geography of the United States (New York: Harcourt, Brace and Co., 1948).

9 Emrys Jones, Towns and Cities (London: Oxford University Press, 1966). 1961).

${ }^{10}$ Jean Gottmann, Megalopolis (Cambridge: M.I.T. Press, 
As in Gottmann's comprehensively large regional study or this research effort on the evolution of a small village established geographical "field methods" have been used. An important reference which describes these techniques is Robert Platt's "Introductory Field Study."1l He delineates those methods of inquiry and mode which were used in this manuscript. He states that in a study on human settlement we must recognize "a pattern of occupance, functionally organized and using an old system set down in a natural environment."12 Platt states that there are three methods of field study: (1) the researchers direct observation, (2) by interview, and (3) inquiry. Interviews may ascertain opinions such as those revealed in a questionnaire or they can elicit factual information from individuals who have direct knowledge of the subject researched. Inquiry is a conscious grasp of objectives to find the answers to pertinent questions. Some questions listed by Platt are:

$$
\begin{aligned}
& \text { What is here and what goes on here? } \\
& \text { What is the system of operations and } \\
& \text { what are its internal and external } \\
& \text { connections? Where did it come from? } \\
& \text { What was here previously? What nat- } \\
& \text { ural conditons does it enjoy or suf- } \\
& \text { fer from? }
\end{aligned}
$$

These and other questions were asked in this paper.

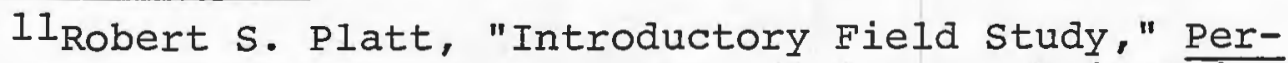
spective in the Study of Geography (Chicago: University of Chicago, 1951).

12

Ibid. p. 13 .

13 Ibid. , p. 14
} 
Since georgraphy is concerned with "spatial" factors and relationships one of the best means of recording these data is through the use of cartographic methods. Erwin Raisz's two books, General Cartography ${ }^{14}$ and Principles of Cartography ${ }^{15}$ have been invaluable aids. Another technical volume, Maps and Diagrams, ${ }^{16}$ is a compendium of cartographic concepts and techniques and has been an extremely useful reference. Edmund Bacon's Design of Cities $^{17}$ is concerned with the spatial and architectural arrangement of settlement. He begins with ancient Greek villages and ends with the contemporary city of Philadelphia. His maps and diagrams demonstrate the need for graphic delineation when the subject matter is of a spatial nature

Another dimension of morphology is that of function. Walter Christaller developed the "central place theory."18 Christaller's laboratory was southern Germany. To him the basic central place was a rural village surrounded by a

${ }^{14}$ Erwin Raisz, General Cartography (New. York: McGraw Hill Book Company, Inc., 1948).

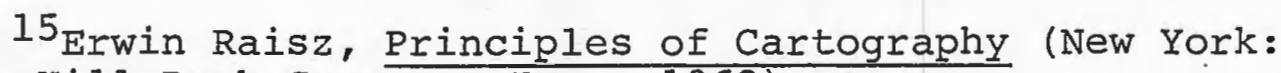
MCGraw-Hill Book Company, Inc., 1962).

${ }^{16}$ F. J. Monkhouse and H. R. Wilkinson, Maps And Diagrams: Their Compilation And Construction (London: Methuen \& Co., Ltd., 1972).

17 Edmund Bacon, Design of Cities (New York: Viking Press, 1967).

18 walter Christaller, Central Places in Southern Germany (New Jersey: Prentice Hall, 1966)|• 
complementary region or hinterland. By assuming a region that is physically homogeneous with uniform transportation potential and evenly distributed consumer purchasing power, Christaller postulated that a pattern of urban centers depends upon traffic movements which create them. In theory centers of equivalent functions are spaced equidistant from one another.

Dean Rugg develops a typology of urban centers which range from the smallest center, hamlet, to the city which is the largest. This urban hierarchical structure is based upon the functions which centers possess. "The hierarchy of settlement, therefore, is first of all established by the provision of different levels of ubiquitous goods and services on a regular basis."19 This research effort charts Kingston's climb up the urban hierarchical structure from a small low level rural junction of few functions, to a higher hierarchical plateau as a regional county seat with a diversity of urban functions, and finally as the location of the only state university within the state giving it a state wide function.

Douglas McManis finds that historical settlements are not easily defined in terms of present day criteria for urban centers and he uses the concept of "urban village." The villages in which political, economic, and professional activities were centered

${ }^{19}$ Walter Christaller, Central Places in Southern Germany (New Jersey: Prentice Hall, 1966). 
were functionally urban places, in some instances from the time of their founding. Yet, to call the urban centers of colonial New England--small indeed by present-day standards--"cities" is misleading. In order to emphasize their contemporary conditions, they are here called "urban villages," a term that differentiates them as unique functional places but still implies small size, an integral relationship with the town, and the presence of agriculture. 20

This concept accurately depicts the village of Kingston in the late 18 th century.

In 1925 Carl Sauer disagreed with proponents of "environmental determinism" and wrote an article entitled "The Morphology of Landscape." 21 Environmental determinists held that environmental factors shape the culture of the inhabitants. Sauer's position was that the natural landscape supplies the material but the culture is the force. $^{22}$ The forms which man creates do not depend upon the natural environment but are shaped by the values of a particular society. Geognostic, climatic, and vegetative factors over time create the forms of the "Natural Landscape."23 The "Cultural Landscape" is created by

${ }^{20}$ Douglas McManis, Colonial New England (New York: Oxford University Press, Inc., 1975), p. 76.

${ }^{21}$ Carl Sauer, "The Morphology of Landscape," Geography II (California: University of California Press, 1925), p. 29 .

$$
\begin{aligned}
& 22 \text { Ibid., p. } 46 . \\
& 23 \text { Ibid. }
\end{aligned}
$$


culture of a society acting upon the "Natural Landscape" over time. It has been generally recognized among geographers that both physical and cultural aspects affect settlement and growth. This study examines both: the characteristics of the site as well as the morphological changes the settlement of Kingston undergoes throughout its development to the present.

Another geographic concept used in this thesis is that of "areal differentiation" or, better put, "areal uniformity" and "areal diversity." It is a statement of the inherent characteristics found in the landscape by observation. In order to separate similar and dissimilar elements one must first have a basis for classification. A. K. Philbrick finds that there are three levels of classification. He states:

First-order classification divides land uses into two kinds on the basis of the type unit area to be used. Where access is by streets in a pattern of blocks, land uses are classified as of the "block" type. At the edges of block-type settlement and between such areas, distances between establishments are greater, or their relation to a road is that of a row of beads to a string rather than that of a "box" containing a cluster. Such more extensive land uses are termed "open" or of nonblock type. The second order distinguishes two basic associations in block-type settlement and three in settlement of open pattern. They are residence and livelihood in the former, and nonagricultural residence and two types of livelihood--agricultural and nonagricultural-the latter. Public, institutional, vacant, and other land uses are held in a neutral status in both kinds of unit areas. An 
additional category, vacant land, is used when the whole of a unit area is unoccupied.

philbrick delineates seven categories which are to be found within unit areas. These are (I) business-industrialtransportation, which he refers to as business, residential, (3) agricultural, which includes agricultural residence, (4) business-agricultural combinations, (5) business-residential combinations, (6) residentialagricultural combinations and (7) business-residentialagricultural combinations. 25

In another article philbrick carries his train of thought further and discusses the inter-connection between the units or as he now calls them, establishments. He superimposes a functional organization on top of the previously discussed landscape of homogeneity and diversification which can be physically observed. These interconnections between establishments are classed as parallel and nodal. $^{26}$ As to parallel relationships he states,

The same pattern of uniformity can be displayed for other types of establishments. Individual residences organized in blocks are connected by streets, sidewalks, alleys, telephones, water mains and sewers.

24 "A Unit Area Method of Mapping Gross Land-Use Associations in Urban Regions", quoted in Robert S. Platt, Field Study in American Geography (Washington: A. K. Philbrick, 1952), p. 296.

\section{Ibid., p. 297}

26 "Principles of Areal Function Organization In Regional Human Geography", quoted in Robert S. Platt, Field Study In American Geography (Mass.: A. K. Philbrick, 1957), p. 338 . 
Interconnections lead away to establishments outside the blocks. Stores are in parallel relationship along the street frontage devoted to business. 27

Using Boswell, Indiana as an example of nodal organization he dipicts it as the center for retail-wholesale marketing, goods and services for the people in the surrounding area. "The focus upon the village makes it the nerve center or node of a sizeable area." 28 Therefore Philbrick concludes:

In summary, then, individual interconnected areal units of occupance possess two kinds of areal relationship simultaneously. In one case it is the parallel relationship of similar-type units. In the other case it is a series of interconnections between unlike establishments focusing upon the core of a nodal area of functional organization. 29

Within this same framework Richard Hartshorne states his view of what would happen when these various classifications.were superimposed on a map of the world,

the total would represent the actual geography of the world as it is, but it would not establish definite regions nor would it establish definite types of areas, but rather would show all the differences actually existing lin specific areas. 30

\footnotetext{
27 Ibid.

28 Ibid., p. 344.

29 Ibid.
}

${ }^{30}$ Richard Hartshorne, "The Nature of Georgraphy," Annals of the Association of American Georgraphers 29 (1939): p. 361. 
Derwent Whittlesey stated that these spatial concepts, of the human occupance of an area, "remain purely descriptive, however, unless they are treated dynamically, i.e. unless the time factor is cognized." 31 He brought forth the concept of "sequent occupance" in which the present landscape is but one stage among a succession of stages of human occupance. He believes that patterns and uses of land have a direct bearing upon future patterns and uses. Whittlesey sums it up in one sentence, "Human occupance of area, like other biotic phenomena, carries within itself the seed of its own transformation. The subject of this study is the transformation of Kingston, Rhode Island through its successive stages of humand occupance using the various concepts and techniques mentioned in this chapter.

${ }^{31}$ Derwent Whittlesey, "Sequent Occupance," Annals of the Association of American Geographers 19 (19人): p. 162 . 
CHAPTER II

PHYSICAL CHARACTERISTICS OF KINGSTON AND VICINITY

The Kingston study area is situated in central southern Rhode Island which is known as South County. It is approximately six miles from the ocean. In general, the land today is wooded although a hundred years ago it was extensively farmed. Why did a village locate here and did the physical features of the land affect this location? An examination of the physical characteristics will shed some light on these questions.

\section{Topography As A Site Factor}

Kingston is situated inland on the crest of a ridge at an elevation of approximately 252 feet above sea level. The terrain varies from relatively steep ridges to low swampy valleys as shown in Figure 2. This topography is the result of preglacial orogeny and erosion, greatly smoothed and filled-in by glacial till and outwash which were deposited about 12,000 years ago. 33

The dominating ridge in the study area is the contiguous Kingston-Rose Hill formation. It is granite-gneiss bedrock mantled with glacial ground moraine. Clifford Kaye

${ }^{33}$ CIifford Kaye, "Surficial Geology of the Kingston Quadrangle, Rhode Island," Geological Survey Bulletin 1071-I (Washington, D.C.: U.S. Printing Office, 1960), p. 342 . 


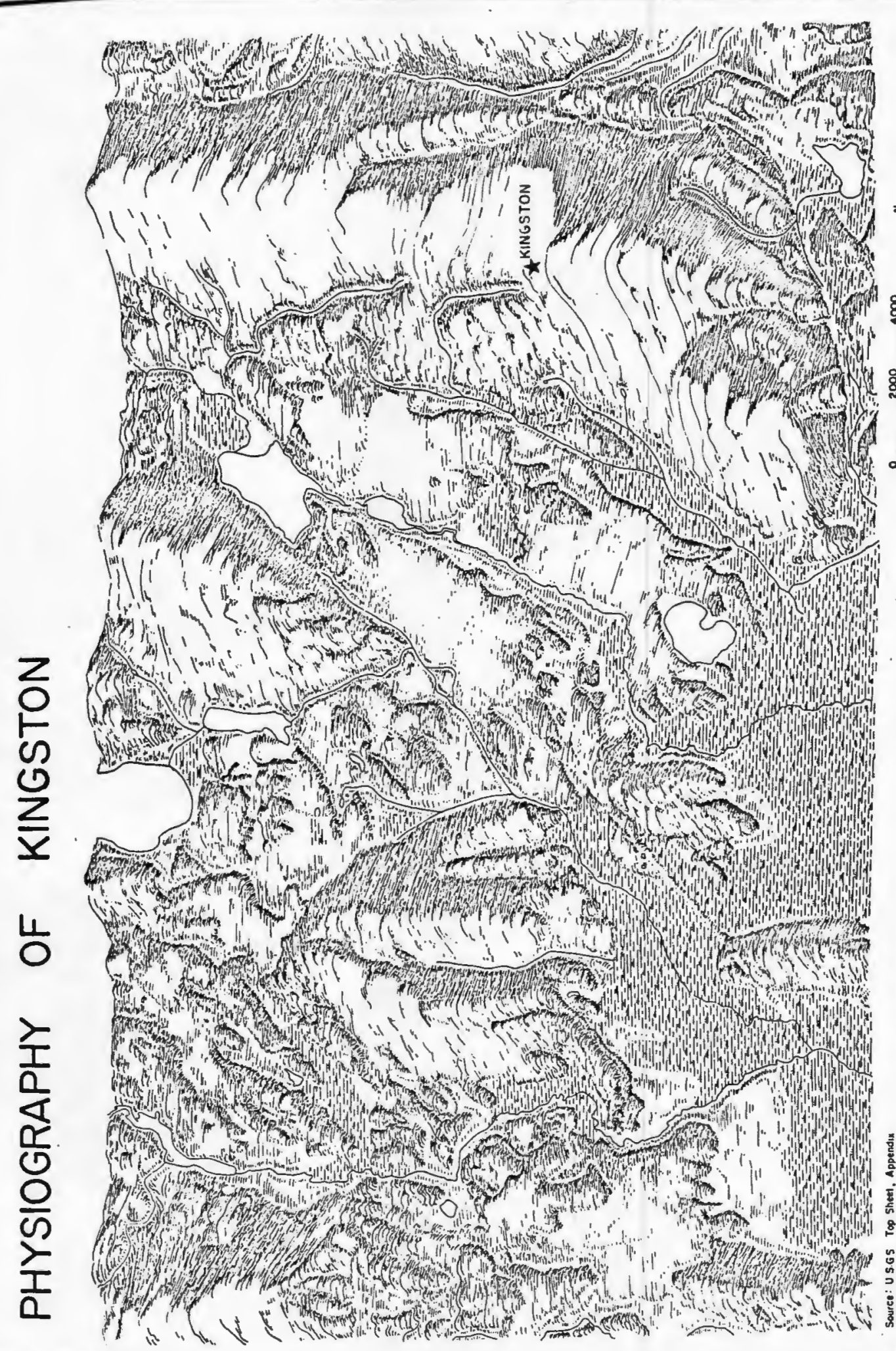


describes ground moraine as "rock debris" that had been embedded in the basal part of the ice (englacial debris). 34 The northern portion of Tobey's Neck and a small area to the north of Asa Pond are also ground moraine depositions. 35 At an elevation of 167 feet above sea level the Curtis Corner hummock is the only other relatively high formation fin the study area. It is composed of undifferentiated ablation moraine deposits which were formed on the surface of the glaciers and as the ice melted they remained as hilly depositions resting on top of bedrock and till. 36

The lowlands of the Kingston vicinity are divided into three categories defined by their depositions as shown in Figure 3. The first is the outwash plain composed of sand and gravel depositions situated west of the kingston ridge. South and west of this is a large swamp with organic depositions which extends eastward skirting the higher formations previously discussed. There is evidence that the Great Swamp was at one time a large glacial lake spilling over into these depressions. The third category includes ice-contact morainal depositions, chiefly sand and gravel, to the east of the Ringston ridge. 37

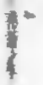

$$
\begin{aligned}
& 34 \text { Ibid., p. } 350 \\
& 35_{\text {Ibid. , plate } 32 .} \\
& 36 \text { Ibid., p. } 352 . \\
& 37 \text { Ibid., plate } 32 .
\end{aligned}
$$




\section{GLACIAL DEPOSITIONS OF THE KINGSTON AREA}

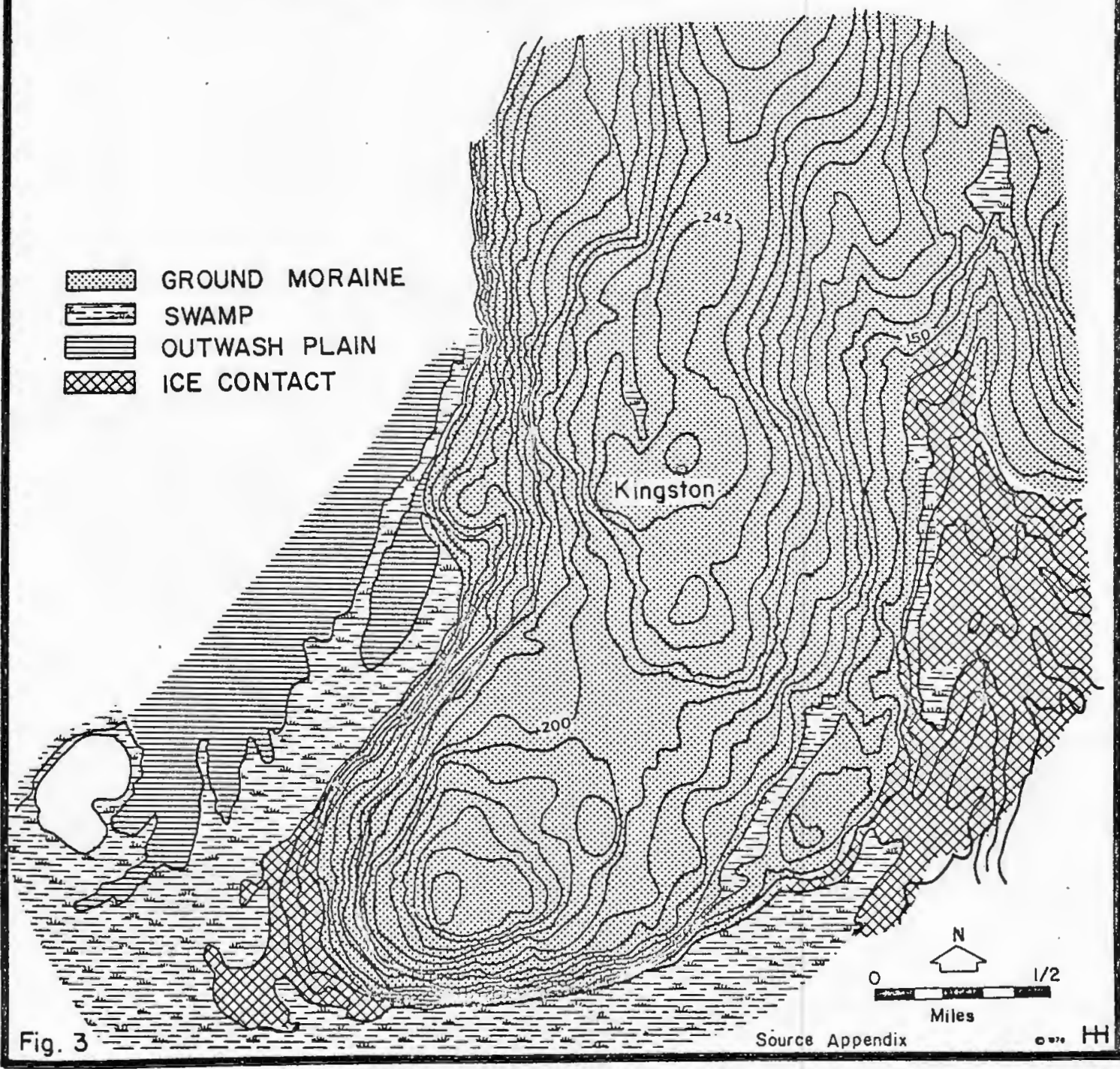


Bedrock

Most of the bedrock in the research area is of a Mississippian Age of between 350-310 million years old. ${ }^{38}$ These formations are Hope Valley Alaskite Gneiss, Ten Rod Gneiss, and fine-grained granite, from which some of the first U.R.I. buildings were constructed in the late 19th century. ${ }^{39}$ Figure 4 shows the location of bedrock outcroppings in the vicinity of Kingston.

Soils

The soils of kingston are good for hay meadow, garden vegetables, and pasture. They are primarily of the Whitman series. 40 whitman silty clay loam is excellent for fine lawns and a wide variety of ornamental shrubs although it is a heavy soil in an area with a high water table. Narragansett stony loam is located to the north of the village site and is not as desireable for agriculture. An excellent soil for, potato culture is located to the west of the study area. It is of the Bridgehampton Series which is less underlain with glacial outwash deposits. A few agri-business farms are located on this soil. These soil types are shown in Figure 5.

\section{${ }^{38}$ Ibid. , p. $26-7$.}

${ }^{39}$ Herman Eschenbacher, The University of Rhode Island (New York: Meredith Publishing Co., 1967), p. 180.

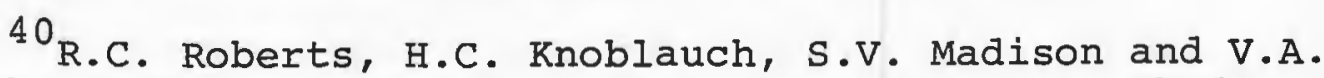
Hendrick, Soil Survey-Kent and Washington Counties, Rhode Island No. $\frac{1}{9, \text { Series } 1934 \text { (Washington, D.C.: U.S. Printing }}$ office, 1939 ), p. 52 . 


\section{BEDROCK OUTCROPPINGS OF}

\section{KINGSTON AREA}

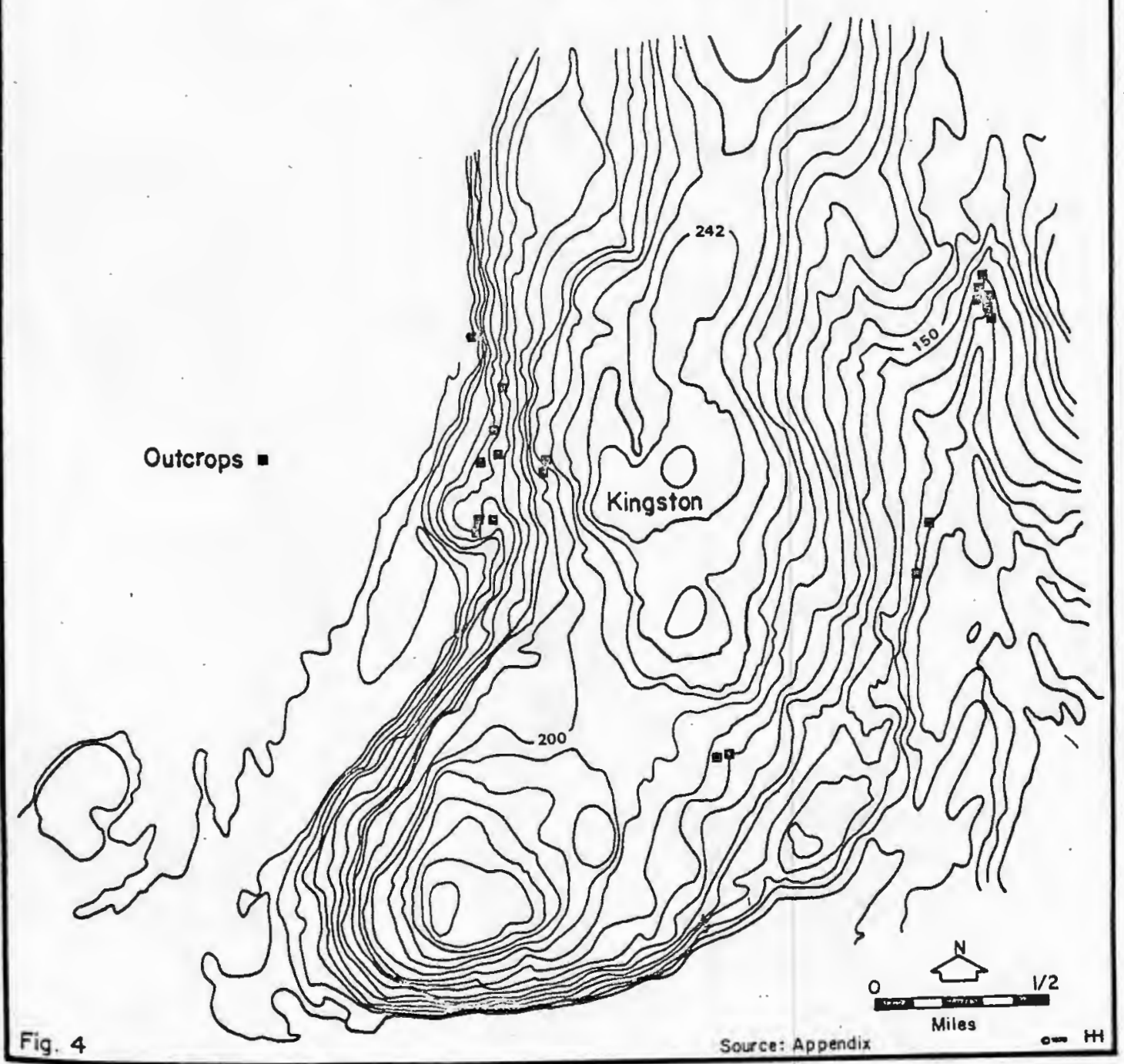




\section{SOIL SERIES OF KINGSTON SITE}

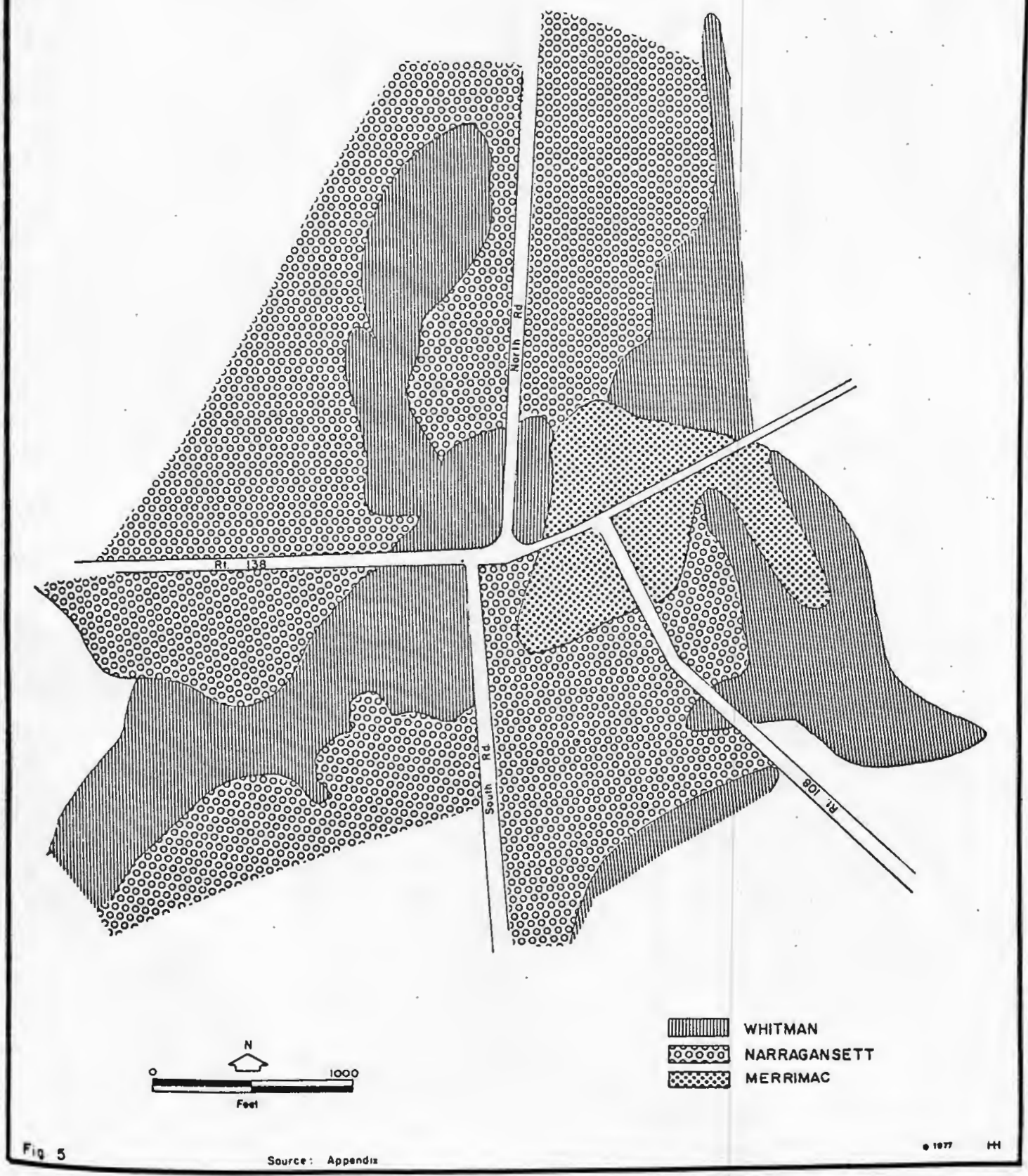


Nater Supply

Kingston ridge is a divide between two watersheds. 'he Pawcatuck River Basin to the west of the ridge is drained by White Horn Brook, Chipuxet River, and Chickasheen Brook which merge to form the Pawcatuck River. To the east of the ridge is the Rhode Island Coastal Basin. 41 It is drained by the Saugatucket River, Rocky Brook and many other small streams. There is an abundance of surface water both to the west and east of Kingston hill. White Horn Brook begins slightly northwest of the village and meanders down the slope of the hill as shown in Figure 6. It provides surface water for the inhabitants very close to the village site.

There is an interesting pattern of bedrock wells which follows the line of the divide between the two watersheds along the top of kingston ridge. This divide is delineated in Figure 6. William Bierschank's water table and geohydrologic deposition maps of the Kingston quadrangle show an abundance of wells and a high water table in the Ringston vicinity. 42

${ }^{41}$ William Allen, Glenn Hahn, and Curtis Tuttle; Geohydrological Data for The Upper Pawcatuck River Basin, Rhode Island (Rhode Island: R.I. Water Resources Coordinating Board, 1963), p. 32 .

42 William Bierschank, "Groundwater Resources of the Ringston Quadrangle," Rhode Island Development Council Geological Bulletin No. 9 (1956): 40 . 


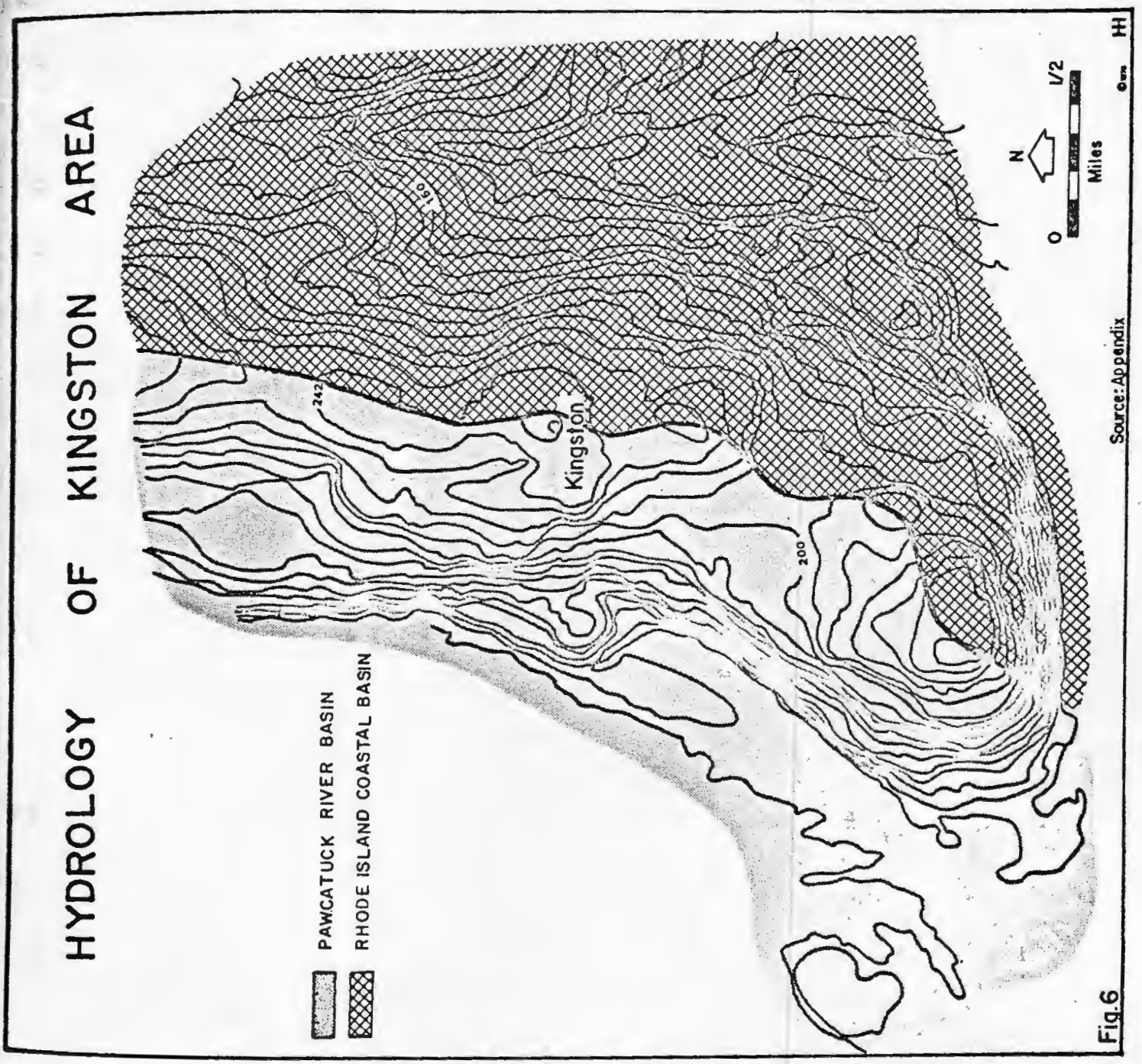




\section{$\underline{\text { Summary }}$}

The Kingston village site is situated inland on top of a hill. Yet, because of its bedrock and surficial geology there is an adequate water supply for a settlement both in small surface streams and in wells. The soil, Whitman loam, is good for growing hay and vegetables but it is a heavy soil and the drainage on the top of the hill is not good. Therefore the water is held by the soil due to its fine compact texture. Excellent growing soil and good drainage is found to the west of the village: There are bedrock outcrops of granite on Kingston hill but these were not quarried for building materials in the early days of settlement. They were used for construction of the first buildings at the University of Rhode Island at the end of the 19th century. Once quarrying began the formations were soon exhausted as they were limited in size.

The general characteristics of the physical environment of the village site were suitable for habitation at the time. However, the site is not unusual nor did it provide a natural focal point. 


\section{THE FIRST LAND DIVISIONS}

Kingston and other historic towns developed within the larger matrix of European business concepts and markets. ${ }^{43}$ The markets were European while land with abundant resources to supply those markets lay across the water. In describing England in the 1580's A. L. Rowse states,

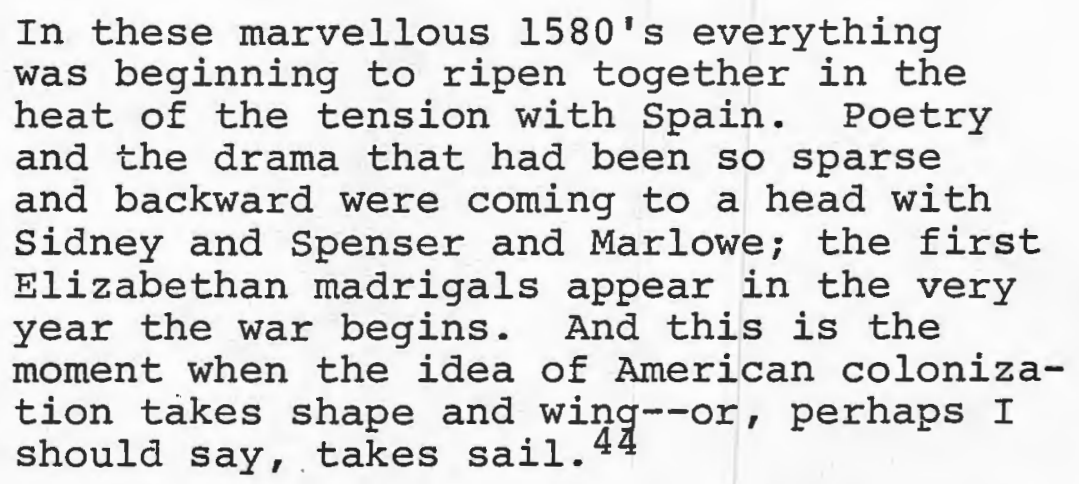

One of the staunchest supporters of American colonization was Richard Hackluyt, the younger. He foresaw the political and economic impact of English colonies in America. His main concern was economic and he thought that furs, fish, and red copper were some of the commodities which England could use while English manufactured wares such as wollens could be exported to the colonies. ${ }^{45}$

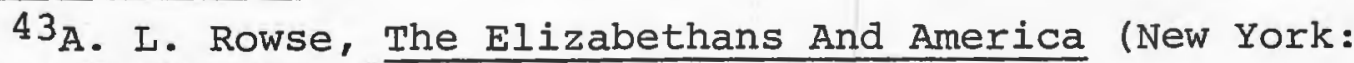
Harper \& Brothers, 1959), p. 46.

44 Ibid. , p. $41-2$.

45 Ibid., p. 46 . 
The most important commodity of all in the New World was land. Those who had the capital to hire men and ships as well as the influence to sway heads of state received patents and rights to the lands and resources so they might be exploited. These influential men were entrepreneurs, assuming the risk for the sake of the profit. ${ }^{46}$ These investors, in turn, created sub-divisions.

Through previous efforts the English claim in America was called "Virginia" but little had come of its colonization or monetary return through commodities or trade. In 1606 a group of powerful men petitioned James I for rights to plant colonies in "Virginia" since the previous patent had by this time lapsed. ${ }^{47}$ This was called the "Virginia Charter" and brought together two entrepreneurial groups: one from western England and one from London who divided the land betwen them.

The southern company was to plant between $34^{\circ}$ and $41^{\circ} \mathrm{N}$. , and was backed mainly from London. The northern colony was to plant between $38^{\circ}$ and $45^{\circ} \mathrm{N}$.; it was backed mainly from Bristol, Exeter and Plymouth, but 48 came to be known as the Plymouth Company. ${ }^{48}$

46 Webster's New Twentieth Century Dictionary of The English Language Unabridged, Revised Second Edition (1973) p. 608 .

${ }^{47}$ Rowse, The Elizabethans And America, p. 63. 48 Ibid. , p. 64. 
Since the topic of this paper concerns an area within the northern colony there will be no discussion of the southern colony here. European interest in the northern section of "Virginia", or what John Smith referred to as "New England," 50 began with commercial fishing ventures. Fishing fleets would appear off the coast bringing with them all the tools of their industry. Temporary shore facilities, such as wharves and areas for dressing fish, were made. However, once the season was over the ships returned to Europe with their catch. 51 The Plymouth Company found it extremely difficult to establish permanent colonies in this northern region. They did not have the capital of their London counterpart, which was more successful. The Plymouth Company itself collapsed and was taken over in 1620 by a new group of investors called the Council For New England 52 Beside grants to corporations, proprietary patents were granted to private persons "to whom were given a grant to territory and various powers of government by the crown." 53

\section{0}

Ralph H. Brown, Historical Geography of The United States (New York: Harcourt, Brace and Co., 1948), p. 8.

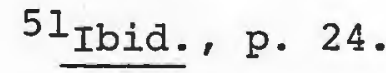

52 Rowse, The Elizabethans And America, p. 105.

53 Charles and Mary Beard, The Beard's Basic History of The United States (New York: Doubleday, Doran \& Co., 1944), p. 7 . 
By 1630 there were three distinct nuclei of English settlement. 54 The northern settlement was located at the mouth of the Piscataqua River including fishing stations along the coast and on offshore islands. The Massachusetts Bay Colony to the south consisted of seven settlements around Massachusetts Bay. The third and southernmost was the settlement of Plymouth. 55

Between 1630 and 1640 many came to America in what became known as "The Great Migration." 56 Interest developed concerning those lands which had not yet been settled. Groups or individuals petitioned the ruling colonial body and/or the Crown for rights to establish new settlements and many left the already established areas for "greener pastures."

Proprietors bought land from the Narragansett Indians and established three settlements between 1636 and 1640 . These were Providence, Portsmouth and Newport. 57 This was the beginning of what later became known as the "Colony of Providence Plantations in Narragansett Bay in New England."

${ }^{54}$ Douglas R. McManis, Colonial New England, A Historical Geography (New York: Oxford University Press, 1975, p. 42 .

$55_{\text {Ibid. }}$

56 Ibid., p. 36.

57John Hutchins Cady, Rhode Island Boundaries 16361936 (Rhode Island: Rhode Island Planning Board, 1936), p. 6 . 
pettaquanscutt Purchase

Kingston is situated on land that was once part of the Pettaquamscutt Purchase as shown in Figure 7 . Originally there were five investors: Samuel Wilbor, John Hull, John Porter, Samuel Wilson and Thomas Mumford. Later William Brenton and Benedict Arnold were admitted to the company. 58 The first deed of transference from the chief. sachems of Narragansett to these proprietors is dated January $20,1657 / 8 .^{59}$ A series of later deeds gave them an area totalling twelve miles square or about 144 square miles. Sidney James states that this was the most successful land purchase made by a group of investors in what later became Rhode Island. 60 The three most influential men in the group were Hull, Arnold, and Brenton. Hull was a prosperous goldsmith in Boston. ${ }^{61}$ Arnold was a Newporter, owner of vast areas of land, and was Governor of the Rhode Island colony for many years. William Brenton was also a Newporter, wealthy, and held the political offices of President, Deputy Governor and Governor of the Rhode Island colony. 62 James states that this body of entrepreneurs

${ }^{58}$ Elisha Reynolds Potter, The History of Narragansett (Providence: Marshall and Brown, 1835), p. 276.

${ }^{59}$ South Kingstown Land Evidence Records, Vol. 2, p. 147. ${ }^{60}$ Sidney James, Colonial Rhode Island, A History (New York: Charles Scribner's Sons, 1975), p. 82.

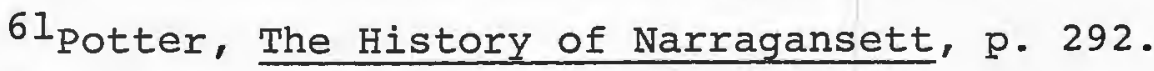
62 Ibid., p. 294. 


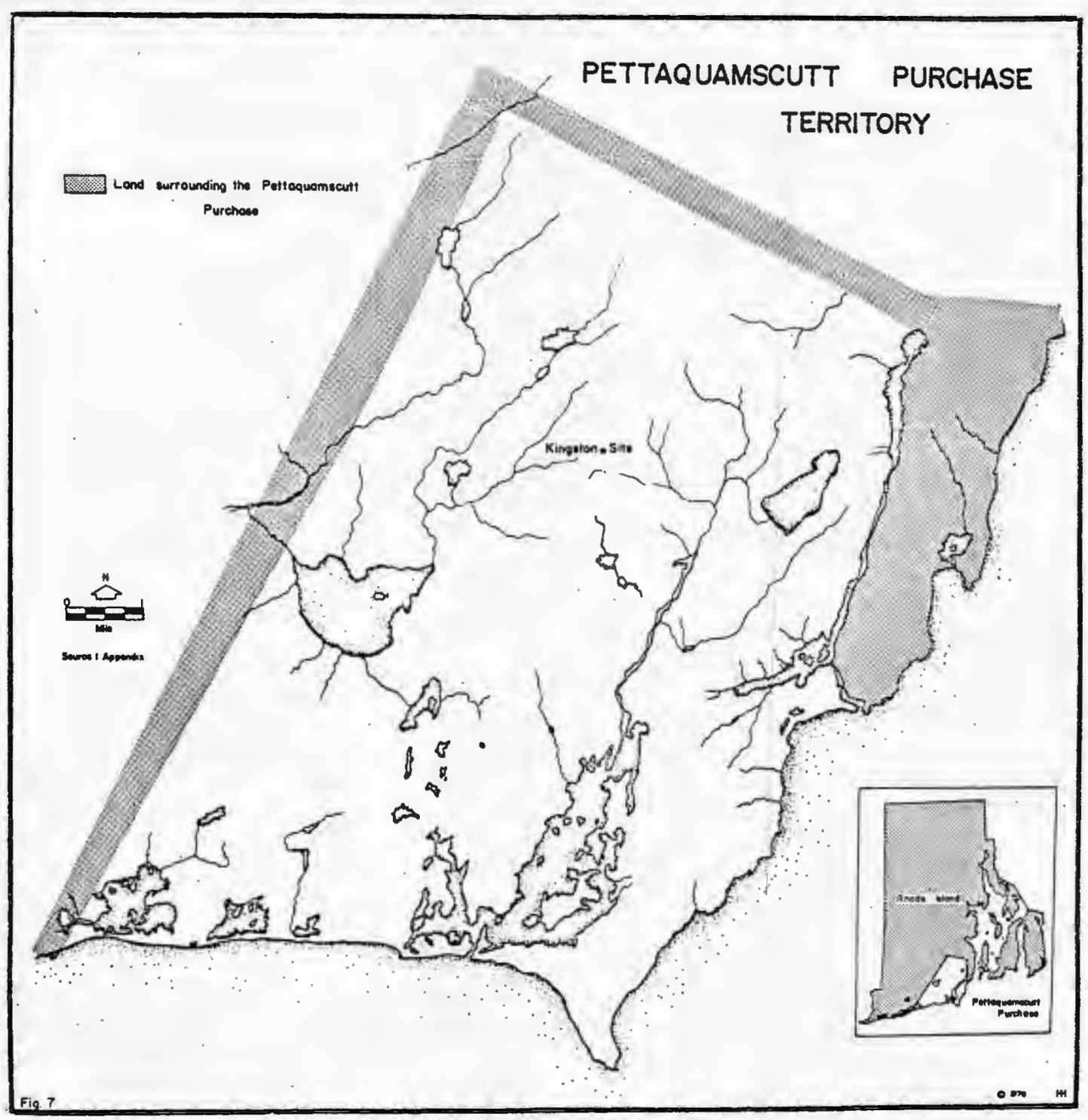


"thought they had a black lead mine and hoped for gold and silver." 63

The partners set aside a tract of 300 acres of land to be "forever set apart as an encouragement, the income or improvement thereof wholly for an orthodox person that shall be obtained to preach God's word to the inhabitants." 64 Instead of setting land aside for a designated religious denomination it was decided to "set it down 'to the ministry,' and let them dispute who has the best title to it." 65 They could win plaudits for dispensing a gift to the church while not creating any enemies. No land was set aside for educational purposes. However, Judge Sewall, who married Hull's daughter and received his share of the Pettaquamscutt land, donated a lot for a school to the settlement of Pettaquamscutt in $1695^{66}$ and a portion of land to Harvard University. 67

The rest of the land was divided by the purchasers into four areas of different character with seven surveyed lots in each. The seven proprietors chose their lots within each of the four areas by taking numbers from a hat. In this manner waterfront, upland, ridges, lowland, and marsh
${ }^{63}$ Sidney James, Colonial Rhode Island, A History, p. 82.
${ }^{64}$ Elisha Reynolds Potter, History of Narragansett, p. 123. ${ }^{65}$ Ibid.
${ }^{66}$ North Kingstown Land Evidence Records, Vol. 2, p. 167.
67 Ibid., p. 104. 
were evenly distributed among them. Provision for a town was accomplished by laying out a series of narrow lots fronting the pettaquamscutt River. The settlement was later called pettaquamscutt. 68 James Helme states,

The Pettaquamscutt Purchasers meant to have a town on the eastern slope of the hill. They laid out house lots there, each of twenty acres. 69

Roads into the interior were necessary to develop and exploit the resources of the Narragansett territory. Thus the proprietors established a network of hinterland roads, shown in Figure 8 , linked to the main road now called "Old post Road." Post Road, the oldest road in the area, was originally an Indian path that ran along Tower Hill ridge. 70 It went north to Boston and south to New York and today is known as R.I. State Route 1. Two roads ran across Tower Hill ridge down to the water. Only one, Middlebridge, exists today. To the west of Middlebridge the "Broad Road" ran from Post Road to the Saugatucket River and ended at Cedar Swamp. The road was reported to have been forty rods or 220 years wide. By this route cedar lumber: and other commodities were hauled out of the interior to the river or up to Tower Hill ridge. By 1726

58 James Helme, A Plat of Captain Henry Bull (Provdence: Society of Colonial Wars, 1926), p. 5 .

${ }^{69}$ Ibia.

70 william Davis Miller, "Ancient Roads in The Pettaquamscutt Purchase," Rhode Island Historical Collections, Vol. XXXIV, No. 3, July 1931, p. 106. 


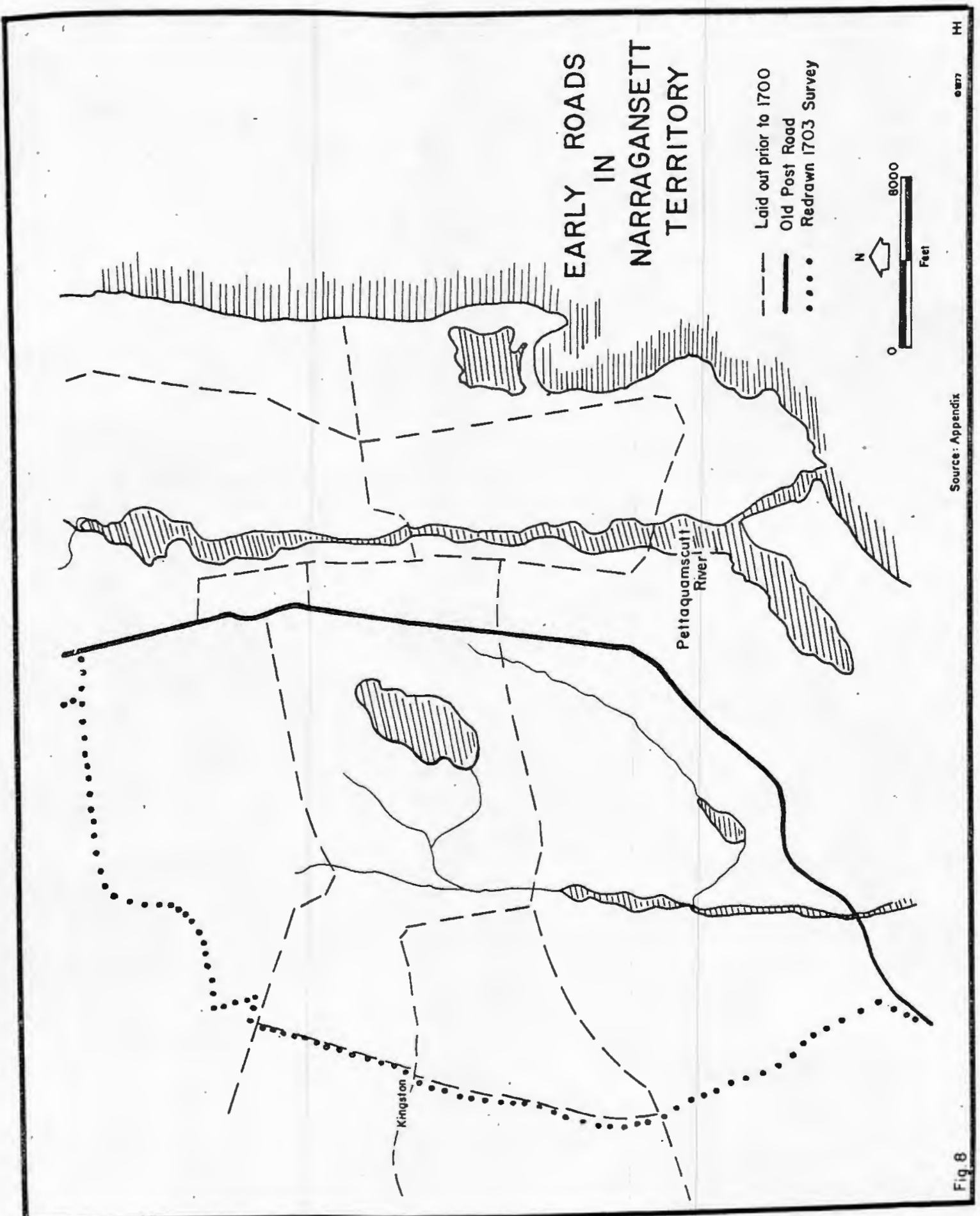


the purchasers decided to reduce the right-of-way to five rods and to divide the remainder of the land among themselves. Today this route is called saugatucket Road. 71 North and South roads were laid out by the purchasers along Kingston ridge in 1670 but were rearawn in $1703 .{ }^{72}$

Occupation of the Land

The first group to occupy the Kingston village site were the Narragansett Indians. These inhabitants shared the land among their people and traveled together over it hunting and fishing. They also cleared their land, for eight or ten miles along the shoreline, and grew corn. 73 After European settlers arrived in New England there was an epidemic which decimated the Indian tribes. This left the meadow lands created by Indian burning practices vacant. Ralph Brown states,

The vacated Indian fields along the southern New England coast at the time of its settlement are further confirmed by reports of the journey of Edward Winslow and Stephen Hopkins of Pokanoket, near the present site of Bristol, Rhode Island, to visit the chief Massasoit. They journeyed along the banks of the Taunton River, where, they said, 'are and have been many towns. The ground is very good upon both sides, it being for the most part cleared.

${ }^{71_{\text {Ibid. }}}$ p. 107 .

${ }^{72}$ Elisha Reynolds Potter, History of Narragansett, p. 107.

$73_{\text {Wilkins Updike, History of the Episcopal Church in }}$ Narragansett, Rhode Island (New York: Henry M. Onderdonk, 1847), p. xii. 
Thousands of men have lived here which died in the great plague not long since, and pity it was to see so many goodly fields so well seated without men to dress and manure the same.' 74

These "Indian old fields" in the Pettaquamscutt Purchase, which was also known as the Narragansett territory, were a great boon to the second occupants. Sidney James states that it was possible to bring livestock onto these cleared areas for little more than the cost of fencing it. 75 The flocks increased on this rich meadow land while the effect of grazing helped keep them open. In discussing his theory of "sequent occupance" Derwent Whittlesey sees a connection between past land use and future use. ${ }^{76}$ Here we have a direct correlation between the clearing of land by the Indians for raising maize and the immediate use of livestock grazing by the second occupants.

The second occupants were the Pettaquamscutt Purchasers and individuals who bought tracts of land from them. It was an economic success for the investors. Their vast lands in many cases were leased to tenants who were obligated to clear and work the land, put up outbuildings,

${ }^{74}$ Ralph Brown, Historical Geography of The United States, p. 17 . p. 252 .

75 Sidney James, Colonial Rhode Island, A History,

${ }^{76}$ Derwent Whittlesey, "Sequent Occupance", Annals of the Association of American Geographers 19 (1929): P. 162. 
fences, look after stock and pay the owner for its use. 77 Selling the land was also no problem for the Purchasers. Shortly after the land was surveyed individuals began to buy tracts until by 1693 all the land was divided into individual ownership. 78

Division of Land At Kingston Site

Wilbor owned a large tract of land west of North Road $^{79}$ while Sewall owned the land east of North Road. 80 To the south Jireth Bull purchased 500 acres between Rose Hill Road and South Road. 81 william Knowles purchased 500 acres between South Road and the Chipuxet River. ${ }^{82}$ These land divisions are shown in Figure 9.

The Bull plat underwent a drastic subdivision. First the northern part was sold to the Case family and the southern section to the Watson family. ${ }^{83}$ solomon Carpenter purchased a portion and built a house circa 1705. 84

${ }^{77}$ Sidney James, Colonial Rhode Island, A History, p. 252.

${ }^{78}$ Ibid. , p. 139

79 South Kingstown Land Evidence Records, Vol. 6, p. 44.

${ }^{80}$ Elisha Reynolds Potter, History of Narragansett, p. 291.

${ }^{81}$ South Kingstown Land Evidence Records, Vol. II., p. 320.

${ }^{82}$ South Kingstown Land Evidence Records, Vol. II., p. I.

${ }^{83}$ Carder H. Whaley and Alfred T. Taylor, "Map of the Town of South Kingstown Washington County Rhode Island," (1933) Made from actual surveys by Henry walling in 1857.

${ }^{84}$ old Houses In. The South County of Rhode Is land (Providence: National Society of the Colonial Dames in the State of Rhode Island and Providence Plantations, 1932), p. 36. 


\section{KINGSTON SITE : FIRST LAND DIVISIONS}

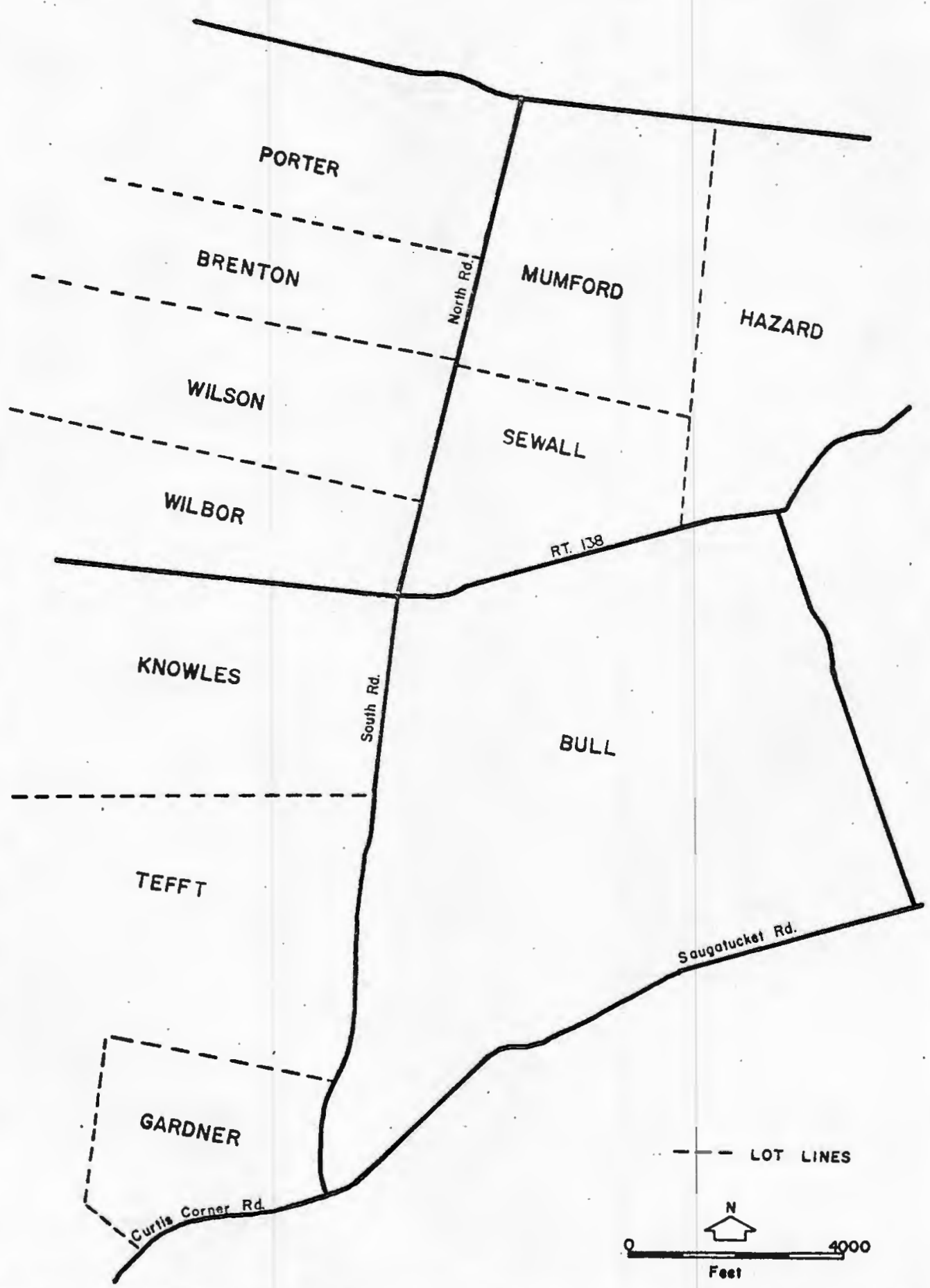

Fig. 9 Source: Appendix 
Rowse Helme owned the southeast corner of the original Bull plat. 85 John Moore purchased two acres at the northwest corner about 1710. When this property was sold to Abraham Perkins, blacksmith, in 1714 the deed contained a record of buildings. ${ }^{86}$

Robert Potter, shoemaker, bought Samuel Wilbor's 200 acres north of main street from Wilbor's heirs in $1684 .^{87}$ He built a house, barn and shop sometime thereafter on the west slope of Kingston hill. Potter divided his land along main street into lots about $791 / 3$ feet each for his children. 88 North of Potter's land, where the University of Rhode I'sland is located, was Samuel Wilson's lot. Upon Wilson's death in 1682 the land was inherited by his daughter, who farmed the land and erected a dwelling. According to tradition the old house burned and a new one was built. This new one is now known as Watson House on the U.R.I. campus. ${ }^{89}$

${ }^{85}$ James Helme, "A Draft of the Highways as they were laid out by the committee appointed by the Town of South Kingstown," 1737, Unpublished map in the U.R.I. Archives. ${ }^{86}$ William Davis Miller, The Removal of The County Seat From Tower Hill To Little Rest, 1752 (Providence: Rhode Island Historical Society, 1926), p. 2 .

87 Elisha Reynolds Potter, History of Narragansett, p. 392. 88 "Walking Tour of Kingston," Pettaquamscutt Historical Society, 1957.

${ }^{89}$ Second Annual Report of the Managers of The Rhode Island State Agricultural School and Experiment Station, Jan. session, 1890, p. 21 . 
Cultural Morphology

These inhabitants were mainly English or of English descent. Many had filtered down to the southern Narragansett territory from the northern port of Boston or its satellites. English culture now replaced that of the Indian.

Intagibles came with them over the seas: English law and precedents, safeguards against tyranny wrought out in courts and Parliament; experience in leet and parish and town government, and thus practice in extremes, in arriving at common-sense solutions; confidence in humane education and in learning; and above all, faith in God. 90

This difference was readily visible upon the landscape. In his discussion of the "cultural landscape" Carl Sauer states that, "The content of landscape is found therefore in the physical qualities of area that are significant to man and in the forms of his use of the area, in facts of physical background and facts of human culture."9l At the Kingston site fields were cleared of trees and stones, houses were built and the result of land division was large plantations.

In most of the older New England settlements houses were nucleated around a center. ${ }^{92}$ This was true of Newport.

$90_{\text {Wallace Notestein, The English People on The Eve of }}$ Colonization 1603-1630 (New York: Harper \& Brothers, 1954), p. 265 .

$91_{\text {Carl Sauer, "The Morphology of Landscape," Geography }}$ II (California: University of California Press, 195), p. 29.

92 Douglas R. McManis, Colonial New England, A Historical Geography (New York: Oxford University Press, 1975), p. 57. 
Providence was laid out by Roger Williams as a linear village ${ }^{93}$ and the settlement at Pettaquamscutt also took this form. The Narragansett territory, of which the Kingston site was part, was laid out as a speculative sale of frontier land. Therefore the population was not nucleated at the kingston site but was in fact dispersed around its main crossroad. At this time it was called "Little Rest" but the name was changed to Kingston in 1826. 94 Throughout this paper it is called Kingston.

It was an area of homogeneous large farms; each having the residence and outbuildings arbitrarily located within the tract. There were no clusters of houses; each was an individual unit. The farms were successful in raising livestock, producing butter and cheese and other agricultural commodities. Most of these commodities were shipped to Newport via Pettaquamscutt for sale. The Narragansett territory was the agricultural hinterland for Newport.

\section{Summary}

The first land divisions of the "New World" were made by those who could secure patents, hire men and ships to exploit these lands. The Kingston site was part of the Pettaquamscutt Purchase. These Pettaquamscutt Purchasers bought an area which was twelve miles square. The investors

93 John w. Reps, The Making of Urban America (New Jersey: Princeton University Press, 1965), p. 138-9. p. $336{ }^{94}$ Elisha Reynolds Potter, The History of Narragansett, 
divided the purchase lands into four areas of different character with seven surveyed lots in each. In this manner the land was distributed among them evenly with respect to varying types of physical features. They llaid the settlement of Pettaquamscutt along Narrow River in long lots. It was the only settlement laid out within the Pettaquamscutt purchase by these investors. They drew a road network to both facilitate the settlement of Pettaquamscutt and to open their interior lands for development. These roads, for north-south travel, followed the ridge formations. With the settlement of Europeans upon land that had originally belonged to the Narragansett Indians a new stage of sequent occupance occurred and a "cultural landscape" based on English precedents emerged. 
KINGSTON'S RISE WITHIN THE RHODE ISLAND URBAN HIERARCHY

In order to understand Kingston's place within the colonial urban hierarchy of Rhode Island it is first necessary to examine some theories of urbanism.

Walter Christaller laid the groundwork for many later theories and studies of urbanization when he conceived a "Central Place Theory". in 1933.95 By assuming a region that is physically homogeneous with uniform transportation potential and evenly distributed consumer purchasing power, Christaller postulated that a pattern or urban centers depends upon traffic movements which create them. In theory centers of equivalent functions are spaced equidistant from one another. R, K. Semple and R. G. Golledge explain the "central place theory" thus:

Deductive reasoning led both Losch and Christaller to postulate the theoretical tendency of equidistance for central places. Both researchers showed that the triangular arrangement of central places and the hexagonal lattice of market areas represents an optimal situation under the

${ }^{95}$ Walter Christaller, Central Places in southern Germany (New Jersey: Prentice Hall, 1966), p. 190. 
assumptions of uniform population densities on an unbounded plain yith uniform access in any direction.

Carrying Christaller's theory of small market centers another step, Dean Rugg creates a hierarchy of centers. He ranks them using the criteria of amount and diversification of goods and services within each center. The more a center contains the higher its rank. Rugg's lowest category is "Hamlet" which he lists as having the fewest functions. "Village" is the second category and it is characterized by such central place activities as: grocery, service station, restaurant, drug store, elementary school and church. The third within this hierarchy is "Town" whose activities are: supermarket, service station, restaurant, drug store, elementary school, church, physician, appliance store, and county court house. The highest designation is the "City". Its functions include: supermarket, service station, restaurant, drug store, elementary school, church, physician, appliance store, county court house, motel, and department store. Rugg states,

The hierarchy of settlement, therefore, is first of all established by the provision of different levels of ubiquitous goods and services on a regular basis. 97

96 R.K. Semple, and R.G. Golledge, "An Analysis of Entropy Changes In A Settlement Pattern over Time," Economic Geography XLVI, April, 1970, p. 157

${ }^{97}$ Dean Rugg, Spatial Foundations of Urbanism (Iowa: William C. Brown Company, 1972), p. 107. 
External support of a center has a direct bearing upon its growth and development. By external is meant the hinterland, or that area which surrounds a center. If it is an agricultural area then its produce can be sold or traded in the market place for other commodities. Since the urban area itself has little if any agriculture it is supported by the produce grown within its hinterland. Mark Jefferson states, "Cities do not grow up of themselves. Countrysides set them up to do tasks that must be performed in central places." 98

It has been recognized that the larger the settlement the larger its sphere of influence or external area. In other words, a central place such as that delineated by Christaller is a small market place sustained by a small surrounding hinterland. However, a capital city would have influence over the whole state and such a large city as New York would have a hinterland of international scope.

Small centers are based on a small hinterland and successively larger settlements enlarge their supporting areas and services offered so that an urban hierarchy exists which reflects, these varying external relations.

${ }^{98}$ Mark Jefferson, "The Distribution of the World's City Folks: A Study in Comparative Civilization," Geographical Review 21, July, 1931, p. 453.

99 Dean Rugg, Spatial Foundations of Urbanism, p. 117. 
Newport - Primate Center For The Rhode Island Colony

The proprietors realized the advantages of Newport's harbor site and used it as a basis for commercial growth. McManis states that, "Newport, the second largest urban center in New England at the end of the Colonial era, had grown primarily as the result of expanding commercial activities after 1713, although it had been involved in the slave trade as early as 1669."100

The founders of Newport established the "Long Wharf" development which consisted of a long wharf, warehouses and shops for the promotion of shipping and trade. ${ }^{101}$ These investors realized the need for fresh capital and consumers for their wares. While most colonies persecuted those of other religions the only requisite for new immigrants to Newport was money. Immigrants, at this time, did not simply decide to live in a colony but had to be accepted. Only those with money were admitted as freeman; others remained indentured until they earned enough to pay debts and so attain first class status. Both wealthy Jews and Quakers were welcomed to Newport where they set up businesses and plantations.

Newport had an international hinterland or what might better be called urban field. Shipbuilding was one of its

100 Douglas McManis, Colonial New England, A Historical Geography, p. 78 .

${ }^{101}$ Lloyd A. Robson, "Newport Begins," Newport History, Vol. 37, No. 4, October, 1964, p. 138 . 
most important industries. This was of course followed by the selling of the goods her ships brought to port. Newport vessels were the "best and cheapest" in the colonies. 102

Although much of the canvas, cordage, and ironwork needed on the larger vessels came from abroad, shipbuilding at Newport actually supported over twenty different arts and crafts, ranging from riggers and painters to tallow chandlers and instrument-mgkers like the famous Benjamin King.

Newport ship captains found profits from cargos in the British West Indies, Africa, Amsterdam, Curacao and the French Caribbean. As one person stated,

Thus with the money they get in Holland, they pay their merchants in London; the sugars they procure in the west Indies, they carry to Holland, the slaves they fetch from Africa they send to the West Indies, together with lumber and provisions, which they get from the neighboring colonies; the rum that they distill they export to Africa; and with the dry goods, which they purchase in London they traffic in the neighboring colonies. By this kind of circular commerce they subsist and grow rich.104

With this prosperity came new homes built by such architects as Richard Munday and Peter Harrison. Furniture made by such fine craftsmen as John Godalard graced the elegant homes. Diversification of goods and services increased until Newport attained a cosmopolitan air.

102 Carl Bridenbaugh, Cities In Revolt (New York: Borzoi, 1955), p. 72 .

$$
\begin{aligned}
& 103 \text { Ibid., p. } 73 . \\
& 104 \text { Ibid., p. } 47 .
\end{aligned}
$$


Newport had become the "primate center" for the Rhode Island Colony. Mark Jefferson describes a "primate center" as the largest city in a region having a greater range of external support than any other city. ${ }^{105}$ It was "the center of wealth, population, culture and government in the colony." 106

Kingston And The Narragansett Territory As Hinterland For Newport

The Narragansett territory was the agricultural hinterland for the city of Newport. It consisted of large plantations and a few low order centers which were characterized by a church and tavern/inn.

The highest ranking center within the Narragansett area was the settlement of Pettaquamscutt. It was located on the side of a hill between the old Post Road to its west and the Pettaquamscutt River to its east. It contained such central place activities as several churches, a school, tavern/ inn and the county courthouse and jail. This last gave the community regional importance. Only a few remnants remain today of this once bustling settlement.

To the west lay the Kingston site amidst the large plantations of the Narragansett Planters. This was a rich agricultural area and the plantations took on the aspect

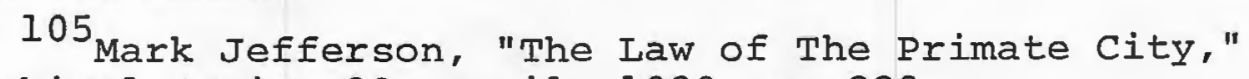
Geographical Review 29, April, 1939, p. 228.

${ }^{106}$ Sidney James, Colonial Rhode Island, A History, p. 2. 
of country estates. They raised sheep, dáiry cattle and a breed of horse called the "Narragansett Pacer."107 The "Pacer" was much prized for its smooth ride and many were sent to the West Indies in ships owned by the planters or via Newport vessels. Robert Hazard, who owned land near Kingston, was reported to have exported 100 of these horses yearly. 108 cheese was another valuable export; Kingston residents such as William Knowles produced and sold it in large quantities. 109 Butter was to a lesser degree an export item. The planters owned large flocks of sheep and fulling mills were erected to cleanse and tighten the wool. Such crops as hemp, flax, corn, rye and some tobacco were also produced. Henry Knowles of Kingston was listed as having seventy-six pounds of "Hemp not Swingled" and twenty-four pounds of "hakkled tow."110 Along with these commodities were garden vegetables, fowl, pigs and other farm enterprises.The main retail and wholesale market for these commodities was Newport. The planters took their produce to market by means of ferries. The first ferry in the colony

107 William Davis Miller, "The Narragansett Planters," The Proceedings of the American Antiquarian Society, April, 1933 , p. 34 .

108 Wilkins Updike, A History of The Church in Narragansett (New York: Henry M. Onderdonk, 1847), p. 515. 109 William Davis Miller, "The Narragansett Planters," p. 37 .

$$
110 \text { Ibid., p. } 42 \text {. }
$$


was begun in 1640 going from the settlement of Pocasset across the northern end of the Seaconnet River. ${ }^{111}$ Before 1700 ferries along the Narragansett shore were private enterprises without colonial regulations or permanence to the operations. However, the General Assembly established guide lines for these ferries from the Narragansett shore to Conanicut (Jamestown) in March 1700 and to Newport in May of that year. ${ }^{112}$ There was so much traffic that John Gardiner petitioned to have more ferries. He states,

that the inhabitants, trade and commerce of this colony have so far increased... that the ferries established on the Narragansett shore... are not sufficient... the boats being crowded with men, women, children, horses, hogs, sheep, and cattle to the intolerable inconvenience, annoyance and delay of men and business.113

By 1747 there were 19 ferries in the colony. 114

As it has already been mentioned the pettaquamscutt Purchase was mainly a Newport hatched scheme and a number of purchasers retained land in Narragansett while residing in Newport. Therefore some individuals were able to have the best of both environments: an exciting cosmopolitan urban

${ }^{11} 1_{\text {Robert Grieve, The Sea Trade and Its Development }}$ In Rhode Island and Providence Plantations (Providence: H. P. Smith, 1902), p. 531-2.

112 Ibid., p. 532.

113 Bartlett, Records of The Colony of Rhode Island, Vol. V (Providence: Knowles, Anthony \& Co., 1860), p. 242. 114 Robert Grieve, The Sea Trade and Its Development In Rhode Island and Providence Plantations, p. 532. 
urban life as well as the leisurely country life of weekend fox hunting and horse racing.

Kingston Prior To 1750

Prior to 1752 Kingston was more a geographic location delineated by the crossing of transportation routes than an urban structure. Early in the 18th century Robert potter had a shop on the western slope of Kingston hill and Abraham Perkins operated a blacksmith shop on the southeast corner of its crossroads. Perhaps it could have been called a "Hamlet" within Rugg's typology.

The crossroads gave the site a focus or what might be called nodality. Furthermore it commanded a central location within the Narragansett territory. However, the most important factor in its urbanization came not from physical features of nodality but from the schemes of its farmer-businessmen residents.

Kingston Becomes The Countyseat

Kingston might have remained a simple crossroad hamlet if residents had not lobbied successfully to obtain the county seat from Tower Hill. In 1687 Pettaquamscutt and the Kingston study area belonged to the Town of Kingstown. ${ }^{115}$ The General Assembly designated Pettaquamscutt as Kingstown's

115 John Hutchinson Cady, Rhode Island Boundaries 1636-1936, p. I1. 
county seat and stated that a courthouse and jail should be built. 116 However, they were not. In 1723 the large area comprising the Town of Kingstown was divided into North Kingstown and South Kingstown. ${ }^{117}$ In 1729 the General Assembly enacted that a courthouse and jail be built near Pettaquamscutt along Post Road in the small settlement of Tower Hill. ${ }^{118}$ This was completed in 1732 .

By 1752 these buildings had fallen into disrepair. According to one source "the village of Iittle Rest was not slow in grasping the opportunity of attempting to wrest from Tower Hill their enviable position of county seat." 119

Lobbyists for Kingston's cause before the colonial General Assembly were Col. Elisha Reynolds, Robert Potter, and Major Latham Clark and their families, all Kingston landowners. They developed a three-fold strategy aimed at situating a new courthouse and jail in Kingston. First they deprecated the run-down condition of the old jail and courthouse at Tower Hill. They feigned concern for the safety of members of the Assembly charging that the dilapidated courthouse could "so endanger your lives as to set

116 Bartlett, Records of The Colony of Rhode Island, Vol. 111 , p. 235-7.

117 John Hutchinson Cady, Rhode Island Boundaries 1636-1936, p. 15 .

118 Bartlett, Records of The Colony of Rhode Island, Vol. IV, p. 432 .

119 William Davis Miller, The Removal of the County Seat From Tower Hill to Little Rest, 1752 (Providence: Rhode Island Historical Society, April, 1926), p. 3. 
in it at this time of Year when a hard storm would almost Blow it down." 120

Secondly, it had become known that Tower Hill residents had applied for Colony money to repair the structures. The Kingston petition stated that such money would be unwisely used and "only thrown away."121 To counter the proposed rehabilitation at Tower Hill the Kingston strategists offered gifts. Robert Potter donated a slice of land for the jail and jail yard, Elisha Reynolds gave another piece of land for the courthouse and announced that the people of Kingston would donate money to build them. All of this was on condition that Kingston would be designated the county Seat. The petition also asked that in return for their gifts Col. Reynolds, William Potter and Major Latham Clarke be made managers of the project and be authorized to collect subscriptions from the villagers. They also were to receive the old buildings at Tower Hill to dispose of them as they saw fit. 122 The petition requested that all sessions of the legislature be held in the new building. Kingston was lauded by its proponents for its location and beautiful environment to show that it had numerous good qualities that Tower Hill presumably lacked.

$$
\begin{aligned}
& 120 \text { Ibid. } \\
& 121_{\text {Ibid. , p. } 5 .} . \\
& 122 \text { Ibid. }
\end{aligned}
$$


As a third stratagem the entrepreneurs promised that three new taverns would be built to accommodate the legislators and guests and that residents would be happy to entertain members of the Assembly and courts in their own homes at their own expense. ${ }^{123}$ Tower Hill residents were understandably angered by this and denied all the allegations of the Kingston petitioners. Kingston won and thus began a new stage in its development.

Kingston As An "Urban Village"

Once Kingston acquired the county. seat it became the governmental center for South Kingstown. These specialized governmental and legal functions spun off a myriad of supporting services. Lawyers took up offices in buildings around the courthouse. Residences with shop additions were erected to provide litigants and legislators with services and commodities. These businesses included silversmiths, a peruke and massage parlor, variety stores, shoemakers, physicians, and tailors. The new taverns were built as promised. The Jo Reynolds and John Potter taverns were situated at the intersection of North and South roads. The taverns were not clustered around the courthouse but were strung out along Main street. These activities are shown in Figure 10. By 1776 Kingston had grown from a simple crossroads to a center of substantial rank due to its governmental functions. 


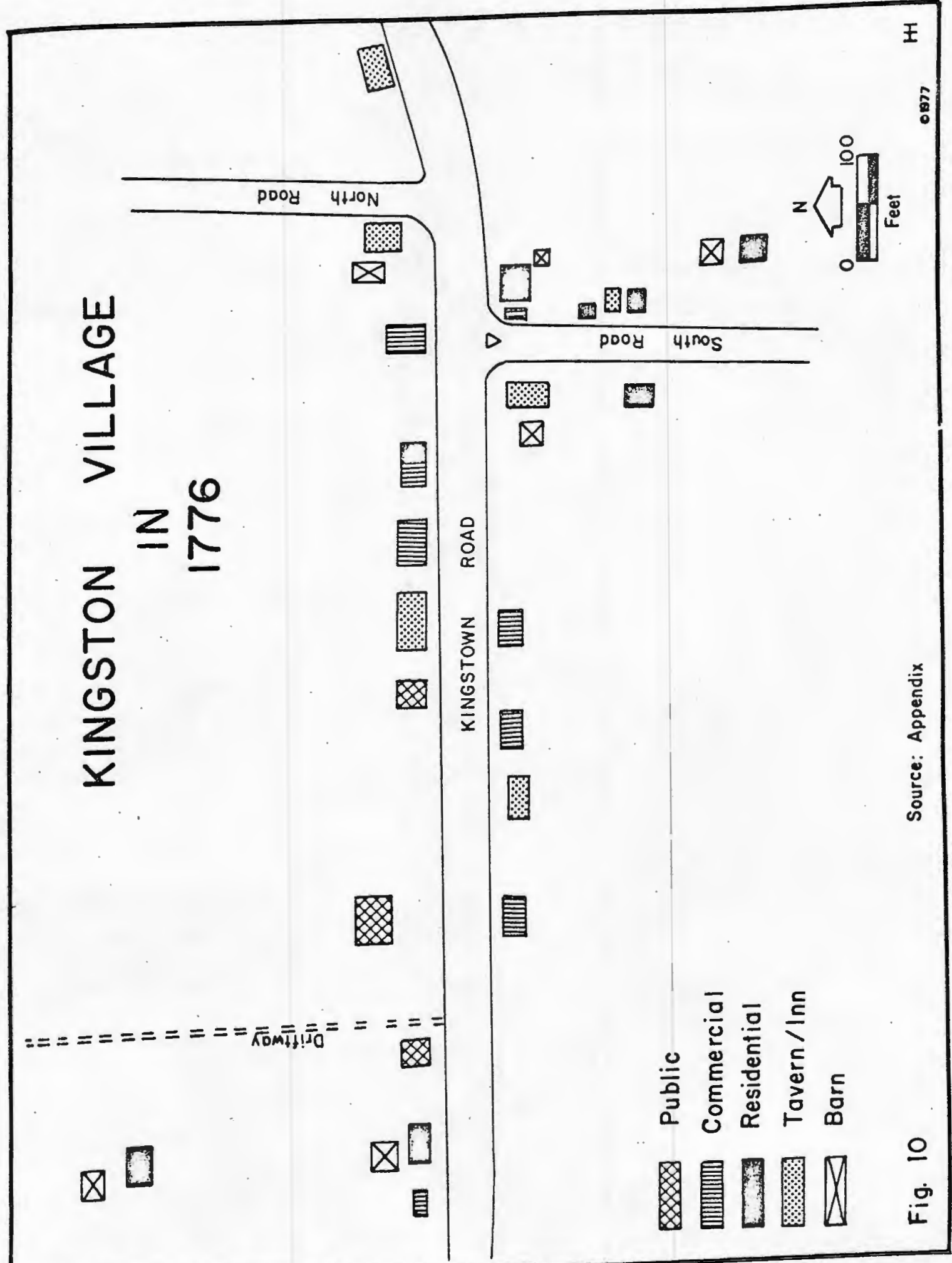


It was known at this time and in the present as a "village." What is a village? To some it means a grouping of people. N.S.B. Gras defines the earliest/villages as social units. He states, "It was a group of people, a social unit, primarily for economic production but also government, religion, and social intercourse." 124 or it could mean a lack of people. Others define village in terms of population as an incorporated place with total population of less than one thousand persons. ${ }^{125}$ Rugg equates the term with urbanization and the quantity of service functions the "village" provides for its external or surrounding area. However, using his scale Kingston in 1776 would have been a "town" rather than a "village" due to its governmental functions and diversified central place activities. ${ }^{126}$ A "village" in the English sense connoted a small community within a rural|setting. The English village is characterized by its nucleated form and such activities as church, school, and tavern, known as the "ordinary."127

Perhaps Kingston in 1776 could best be described as an "urban village." Douglas McManis states that they were,

The villages in which political, economic, and professional activities were centered were functionally urban places, in some

${ }^{124}$ N.S.B. Gras, An Introduction To Economic History (New York: Harper Bros., 1922), p. 50 .

${ }^{125}$ John Fraser Hart, Neil Salisbury, and Everett Smith, "The Dying Village And Some Notions About Urban Growth," Economic Geography, XLIV, Oct., 1968, p. 343.

126 Dean Rugg, Spatial Foundations of Urbanism, p. 107.

127 Wallace Notestein, The English People on The Eve of Colonization 1603-1630 (New York: Harper \& Bros., 1954). 
instances from the time of their founding. Yet to call the urban centers of colonial New England--small indeed by present day standards--"cities" is misleading. In order to emphasize their contemporary conditions, they are here called 'urban villages', a term that differentiates them as unique functional places but still implies small size, an integral relationship with the town, and the presence of agriculture. 128

McManis's definition fits Kingston's urban external functional structure as a regional center while at the same time takes into account its internal structure of small size, few industries and agricultural presence.

Areal Organization and Change In Rank

Kingston's areal organization had begun as a low level infra-structure characterized by homogeneous farms having an internal structure of both nucleus and primary focus, the nucleus being the farm dwellings and the agricultural area as the primary focus with each farm unit set off according to ownership or jurisdiction. It had now become what Allan Philbrick describes as a center having a second order functional organization. ${ }^{129}$ It contained both a primary focus or core of differentiated establishments and a peripheral hinterland area made up of individual farm units.

${ }^{128}$ Douglas McManis, Colonial New England, A Historical Geography, p. 76 .

129 Robert S. Platt, "Principles of Areal Functional Organization In Regional Human Geography," Field Study In American Geography, (Mass.: A.K. Philbrick, 1957), p. 345. 
More important than this Kingston now surpassed the other second order centers within South Kingstown in urban rank due to its unique specialized function as county seat for King's County and one of the locations for the travelling legislature which met in the courthouse. In this way Kingston held a prominence within the colony as a whole.

Sequent Occupance and Cultural Landscape of Kingston 1776

Sequent occupance and cultural landscape concepts use the same indicators for their manifestation, such as dwellings, land use, etc. These concepts are related in many ways and yet one must not forget that they are separate perspectives on the changes an area undergoes over time.

As stated earlier the Kingston site had seen a procession of inhabitants from the Indians to the entrepreneurs who sold it to farmers. These farmers became wealthy Narragansett planters intensifying their agricultural pursuits for profit in Newport, living in a much more elaborate style than had been known in the region earlier. By 1776 Kingston had gained population from such settlements as Pettaquamscutt and Tower Hill. The land use along main street had turned to shops and the surrounding land continued in agriculture. As the early settlers were able to take advantage of the Indian oldfields so the next generation and newcomers were able to take advantage of the new prominence the village had achieved with the location of the courthouse. No new succession of occupation had taken place but a change in 
land use, emergence of a business core, more structures and more intensive agriculture.

Culturally these inhabitants' ancestors were European. In their initial building stage their homes were constructed in similar fashion to those in Europe but there were constraints in a wild country not yet tamed and so form followed need. In Rhode Island a variation developed called the "stone-ender." One side of the house was taken up almost entirely by a huge chimney. This was not European but American. By 1776 architects were embellishing homes in America as well as Europe but a new culture had sprung from the old and it was expressed as much by the new design motifs on houses, such as Newport's scallop shell, as it was in business matters, and ultimately in the establishment of the United States.

Kingston's morphology changed as its citizens turned toward business pursuits which formed, in turn, a strip of businesses along either side of Main street. Houses, clothing, furnishings and manners were of a more refined nature than the days of those early stone-enders. 


\section{Summary}

Kingston had grown within the Rhode Island colonial urban hierarchy. It originally was little more than a junction of two roads but with the establishment of a courthouse became a village. It developed an urban business core of shops and professionals also offered their services.

It had been linked to Newport and Pettaquamscutt through governmental and business pursuits. Newport was the primate center for Rhode Island and Kingston functioned as part of its hinterland. Agricultural commodities shipped to Newport brought profits either in ready cash or were used in business ventures. By the late 19th century a new technology would be introduced and its impact would be felt by communities such as Kingston. 


\section{CHAPTER V}

\section{KINGSTON IN AN INDUSTRIAL AGE}

By 1800 a new technological age emerged. The impact of Slater's mill in Pawtucket touched all of New England, particularly the northern section of Rhode Island. Textile factories were built; great influxes of immigrants and rural settlers arrived in these new mill towns to be employed as factory workers. dities grew rapidly where only a few short years before quiet villages existed. Towns situated along waterways such as Pawtucket, Providence and even Peace Dale became mill and factory centers.

Urbanization through the catalyst of industrialization must have had the character of a modern rock-concert happening taking place on a large farm with thousands of participants camped in the fields. The rural environment was attuned to a different lifestyle and was not equipped to handle the social consequences of this rapid rise in population nor provide bașic needs. New industrial cities were considered dens of iniquity by the general public for squalid conditions which existed in most of them. It was the period of the New England industrial town. 
At Lowell, Massachusetts, for instance, five hundred workers huddled in crude shacks along the canal. 131 Those agricultural and shipping industries in Rhode Island, which had been based on the export of raw commodities and the triangular trade, declined as rapidly as the industrial towns rose to prominence. Providence soon surpassed Newport to emerge as the center with the greatest population and investment opportunities in the state. As a hill town kingston lacked the geographic situation for a mill and also faced decline as an urban center since it was tied to Newport's obsolete businesses. Kingstonians therefore shifted their attention toward Providence and the opportunities which might lie in having their village linked more directly to its economy. They set about to find some stimulus to the town's growth and development which might match that successful abduction of the courthouse and jail from Tower Hill in the previous century.

In the past several attempts had been made to collect money for the construction of a church but subscriptions had failed. 132 However, in 1820, as part of their effort to remain a viable community Kingstonians erected their first church building. The Rev. Oliver Brown was employed as minister and teacher. The building now known as the

131 Ibid.

132 Elisha Reynolds Potter, The Early History of Narragansett (Providence: Marshall and Brown, 1835), p. 376. 
Tavern Hall Club became the temporary home for Rev. Brown and a new school called the Pettaquamscutt Academy. At first the school was a success and soon others followed. Originally commercial development in the town had relied upon judicial and governmental personnel for success. These old service industries, particularly the taverns dwindled. They were incompatible with the new church and the boarding school which served children of the state's business and landholding elite. It was necessary to create a new image for the settlement. The entrepreneurs quickly grasped the situation and the taverns were slowly phased out to become rooming houses by mid-19th century. Business opportunity clearly depended upon a clean moral environment in which tourists could spend a restful summer and to which parents could entrust their children without fear of obvious vice. Private school brochures lauded the tranquil charm and moral quality of the village. It was praised as "Uncommonly free from the temptations to which the morals of the young are often exposed"; good use was made of the new church in that all students of the Kingston Academy were "to attend morning and evening prayers in the chapel," and as if to erase from the public mind its former convivial image parents were assured that "No student shall on any pretense whatever, visit or be loitering about those places where ardent spirits are sold."133

133Kingston Academy Catalogue of the Trustees, Instructors and Students, 1833, p. 5 . 
Later in 1826 another building was completed for the academy. It was renamed the kingston Academy. ${ }^{134}$ It too, was such a success that in 1832 new additions were made to accommodate more students. Students came from all over the state as well as from New Bedford, Nantucket, Charleston, the West Indies, Azores and Minorca. Dr. Carl Woodward writes that,

Rhode Island's best known families were
represented by scions destined in later
years for positions of public prominence.
On the register for 1832 , for example
appears the name of Henry lippitt, Gov-
ernor of Rhode Island 1875 to 1877.135

The curriculum was concerned with subjects that were useful to the upper class such as Greek, Latin, Surveying, Mathematics, English, and Modern Languages, 136

Soon other schools were started in Kingston hoping to capitalize on the Academy's reputation. These are depicted in Figure 11. The Tavern Hall Club, the site of the first private academy, soon became the Potter-Vernon School. It was followed in 1848 by Rev. Jolel Mann's school which was teologically oriented. The Rev. Mann was concerned with the "Revelations of Saint J ohn."137

134 Carl Woodward, "Kingston's Cultural Heritage," The Rhode Island Yearbook (1970), p. 59.

135 Ibid. , p. 60.

136 Kingston Academy Catalogue of the Trustees, Instructors and Students, 1833, p. 5 .

137Carl Woodward, "Kingston's Cultural Heritage," p. 59. 


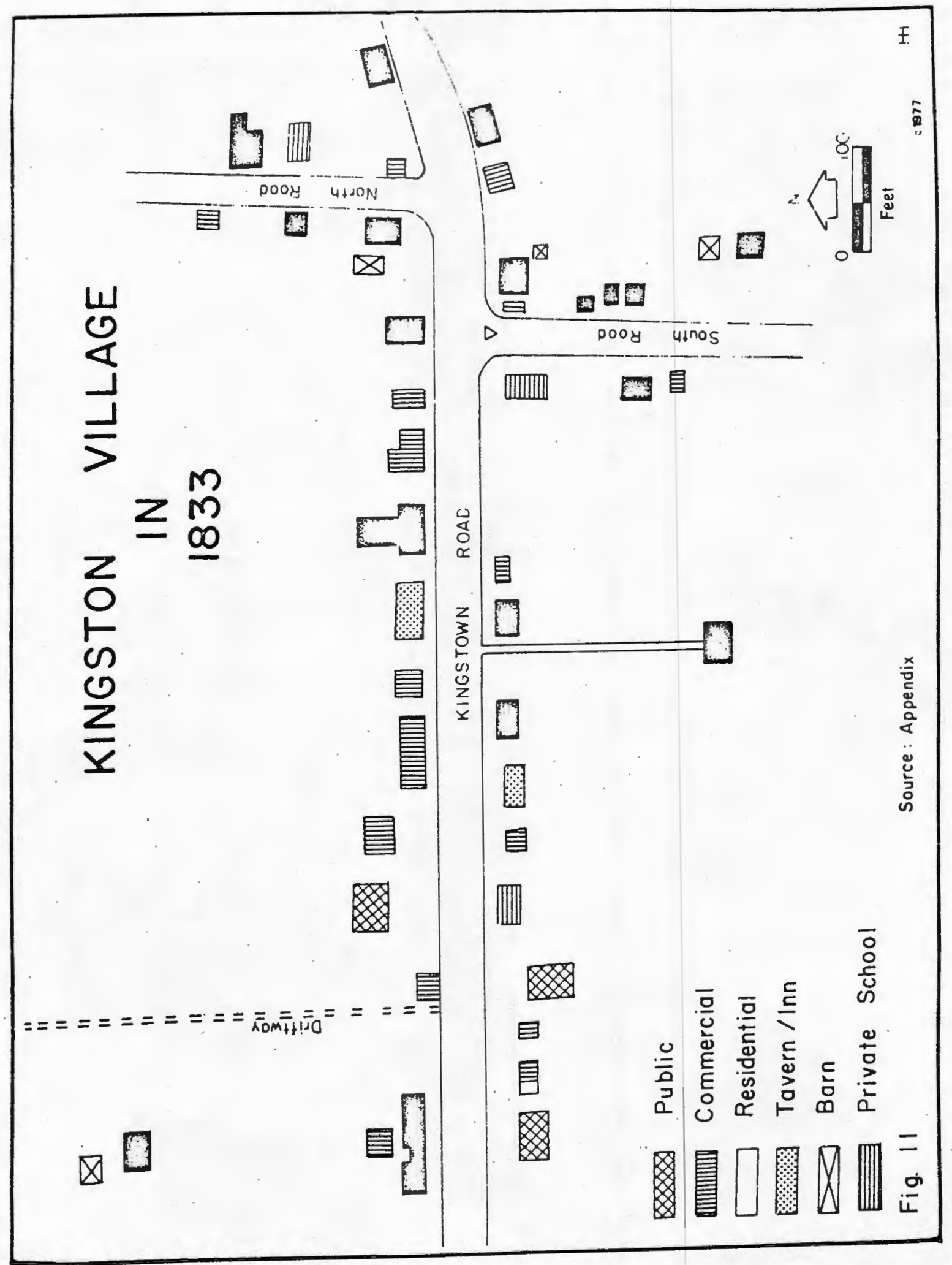


The present Congregational church house became a school conducted by Rev. Hagadorn Wells and was called the Latin school for Boys. He was in charge of the school for five years until he became the pastor of the church. Kingston had become a specialized urban center catering to an influential monied group. The appointment in 1849 of a Kingstonian, Elisha Potter, $\mathrm{Jr} .$, as Commissioner of Education undoubtedly had a connection with the continuation and propagation of the boarding school industry. 138 Kingston had become known for its tranquil rural character through the promotions of the boarding school entrepreneurs. Contemporaneously the village became known as a summer tourist center. Kingston had long been a depot for stage coaches, the mail and freight wagons. In 1837 the Stonington Railroad was completed and a station was built at west Kingston two miles from the village. 139 Tourists were met at the station and driven to Kingston hill for relaxation before continuing their overland journeys. Soon urban tourist and traveller alike were enjoying its fresh air environment. Many boarding houses served a dual purpose by catering to private school pupils during the school term and as tourist homes in summer.

The village seemed to be doing well in its new role as an elite boarding school and tourist community but then

138 Ibid.

139 Historic Buildings of South County, Pettaquamscutt Historical Society and R. I. Bicentennial Commission, no date, p. 40 . 
difficulties arose. A debate swirled around the need for public education especially in view of the stifling effect of the urban factory environments upon those children living there such as northern Rhode Island. In 1836 the "Children's Friends Society of Rhode Island" was formed and a reform movement was launched for mass public education. 140 Numerous frictions developed between the Kingston Academy Trustees, the Trustees of the Sewall Fund and the public school system. ${ }^{141}$ The new Kingstonian venture into private schools was challenged by the notion of publicly financed education.

In the last ditch effort to prop up their private school business the Trustees of the Kingston Academy decided to erect a new building for both boys and girls which was called the "Female Seminary and Family School For Boys." 142 Dedicated in 1853 it proved to be a disappointing venture for it did not attract sufficient students. While the name was later changed to the"Kingston Female Seminary" even that did not alter its fortune for it was sold in 1863 to satisfy creditors. ${ }^{143}$ The fatal blow to the private

140 Rhode Island: A Guide To The Smallest State, W.P.A. Project (New York: Houghton Miffline Co., 1937), p. 80. ${ }^{141}$ Dr. Carl Woodward, "Kingston's Cultural Heritage," p. 60 .

142 "Female Seminary and Family School For Boys Brochure," Dec. 21, 1854, Kingston Archives.

143 Dr. Carl Woodward, "Kingston's Cultural Heritage," p. 62 . 
school business in Kingston occurred when the Academy caught fire and burned to the ground. A new public school system was then implemented which resulted in the demise of Kingston's private school specialization.

The 19th century witnessed perhaps more fully than any other period in the United States history the realization of the "Entrepreneurial Dream." Vast territories beyond the Allegheny Mountains were opened for homesteading and later new trains pushed farther and farther west. Once gold was found a great migration followed. The hope to become an instant millionaire beckoned a number of Kingston residents to the west to seek their fortune. Most, however, attempted new entrepreneurial schemes at home. These new ventures proved short lived. The Kingston Boot and Shoe Co. was launched but shortly went into debt. A newspaper called "The Rhode Island Advocate" was published in the village but was not a success. Entrepreneur Cyrus French began a beaver hat factory in the village and "when the manufacture of hats ceased to be profitable he resorted at once and vigorously to cultivation of his lands and sought and seized upon the instruction of agricultural science and experience with avidity. " 144

The toursit industry also met with decline due to the ocean location and liberal lifestyle of Narragansett 
which soon surpassed Kingston. Some vacationners arrived in Narragansett by ferry, and, after the Pier Railroad was completed in 1876 the overland tourists went directly to the beach, bypassing Kingston altogther. Narragansett grew to become a tourist mecca and to this day is still inundated with "summer people."

Besides Narragansett other centers developed and took a challenging position to kingston's urban rank. Rowland Hazard began the manufacture of hand loomed linseywoolseys at the beginning of the 1800's in Peace Dale. A set of carding-machines soon followed which carded the wool into rolls, and once power looms were invented four were purchased and installed at the Peace Dale mill in 1815. 145 New technology continued to be added; buildings were erected and their output included kerseys, fine wool, shawls, worsted goods, and worsted coatings. As the mill grew so did the village of Peace Dale. To the south was the village of Wakefield. It too had a mill and was situated along the line of the Narragansett Pier Railroad. Enough traffic was generated by the growth of these centers to warrant a new road which connected the three: Kingston, Peace Dale and Vakefield. Kingston's state governmental functions were also in a decline because the state Legislature met only in Newport and Providence from 1854 to 1900 after this only in Providence. By 1878 a new Hoag, Wade \& Co., 1878), p. 295. 
"townhouse" or town hall for South Kingstown was being constructed in Wakefield. Prominent residents of Wakefield contributed to this undertaking just as the Kingstonians had in the previous century. 146

Rhode Island College of Agriculture and Mechanic Arts

Young people left the farm to work in the new industrial centers and farming fell into a depression. Farmers in Rhode Island thought that a state agriculture school situated in a rural environment might help their cause and keep their young people from deserting the land. So, exercising their political influence, the Rhode Island College of Argiculture and Mechanic Arts was founded at Kingston in $1892 .^{147}$

Originally the land grant money, steming from passage of the Federal government's Morrill Act, went to Brown University. Brown was situated in Providence and was known for its classical, rather than technical, approach to education. With the passage of the Hatch Act in 1887, which granted an additional $\$ 15,000$ to each state for establishment of an agricultural experiment station, the farmers became angry. ${ }^{148}$ They feared the Hatch Act grant

\section{$146^{\text {Ibid. }}$}

${ }^{147}$ Herman F. Eschenbacher, The University of Rhode Island (New York: Meredith Publishing Company 1967), p. 7. $148_{\text {Ibid. }}$ 
also would go to "city slickers." Eventually they obtained legislative support for the establishment of a combined college and experiment station devoted to their agrarian interests. A committee was formed to select and purchase a suitable location for the new school and $\$ 5,000$ was appropriated for that purpose.

The new research and institutional establishement was located in Kingston due to the quick maneuvering of three residents. Bernon Helme was a Kingston shopkeeper. His store and post office were located in the building which now house the Art Association workshop. He got the idea one day while talking to the Rev. Hagadorn Wells. 149 Together they recalled Kingston's long history as a renter of rooms to legislators and to students of private academies. The watson farm just northwest of the village was in disrepair and could be bought, they understood, for $\$ 5,000$ which just happened to be the same amount that had been appropriated by the state for purchase of the site of the Argicultural School and Experiment Station.

The other two proponents were Mr. Thomas Hazard, past President of the State Grange, and Jeremiah G. Peckham, President of the Grange. Peckham had a particular interest in the Watson farm; it was his birthplace. "With Yankee shrewdness seasoned with a laudable spirit of liberality, they planned their strategy."150 Helme and his associates

149 Hagadorn Wells, "Reminiscences of Little Rest," p. 49. ${ }^{150}$ Carl Woodward, "Kingston's Cultural Heritage," p. 57. 
collected $\$ 2,000$ from local residents. Also, "The town offered two thousand dollars in connection with this provided it should be located at Kingston." 151 This was the same "free-gift" strategy which had been successful in gaining the courthouse. When the Kingston site was chosen it aroused protest against the "capitalists" on Kingston Hill. 152 A debate developed between Helme and some members of the South County Grange. Philip A. Money was "astonished that a subscription of two thousand dollars by the capitalists of Kingston Hill should give them any power to dictate to the committee."153 However, the Grange's State Master, Jeremiah G. Peckham stated, "that a number of elderly ladies had given their money with the understanding that the buildings were to be located near the village, and would it be right to break faith with them?" The principal criticism of the chosen site was its location with respect to transportation. Students had come to the college from all over the state and many could not afford the boarding fees. Travel by horse and wagon was not the most suitable mode of transport. The railroad was much more convenient but the nearest station was located in West Kingston. Representative George Barstow introduced a bill into the legislature stating that the school must provide free transportation for students to

I5l"Narragansett Times," Be. 22, 1889, U.R.I. Archives, no page numbers.

152 "Narragansett Times," Feb. 15, 1889, no pages, U.R.I. Archives. 
and from the depot. The bill was passed ending debate over the transportation issue. ${ }^{154}$

The college would never have been located in Kingston without the support of local entrepreneurs. The college survived its first hectic years and its name was changed to Rhode Island State College in 1909 after its alumnae had difficulty obtaining city jobs with an agricultural diploma. As one alumnus said "Why should a graduate be handicapped at the start?"155

As Rhode Island State College became well established the community continued to expand along the highways. "Lower College Road was the main entrance to the campus and Upper College Road only went about as far as the stone gates and the rest was just a cartpath."156 However, Upper College Road became a full fledged road and the main entrance to the campus. Gradually Kingston's economic base changed from that prevailing in 1850. By 1895 there was only one tavern along the main street. The private academies were totally out of business and the village central place functions fell into three categories. The first was institutional. Such services were grouped together at the western end of the village around the intersection of main street and Upper College Road. They

\footnotetext{
p. 106 .

${ }^{154}$ Herman Eschenbacher, The Univeristy of Rhode Island, 155 Ibid. p. 44.

156"Burgess Interview, "Manuscript in U.R.I. Archives.
} 
included the new Rhode Island School of Agriculture and Mechanic Arts, the jail, the church and the courthouse which was later used a a public library. The court's functions were moved to a new building in west Kingston in 1900. The second category was commercial and those activities were situated on main street betwee Upper College Road and North Road. The final category consisted of apartments and rooming houses. These are shown in Figure 12 .

Recent Growth and Land Use Changes

Even though the new agricultural school was located at Kingston most of the village's commercial functions steadily declined. However, the enterprise which provided room and board to faculty and students at the new school enjoyed steady growth. Gradually silversmiths, tailors, shoemakers and retail shops disappeared while the boarding houses multiplied. When the courthouse was removed to a fine granite structure in West Kingston no state government functions except the jail remained in Kingston itself. One observer viewed the decline this way,

It is a notable historical fact that as long as there was a genial boniface to exterid the glad hand of whole-souled hospitality to chance wayfarers, Little Rest prospered. The fact sticks out on the pages of history above all others. But finally the ancient village began to flirt with the demnition bow wows; enterprise began to go criss-cross, and Little Rest, began to make progress backward.

In looking over its two centuries of existence those who were endeavoring to diagnose the 


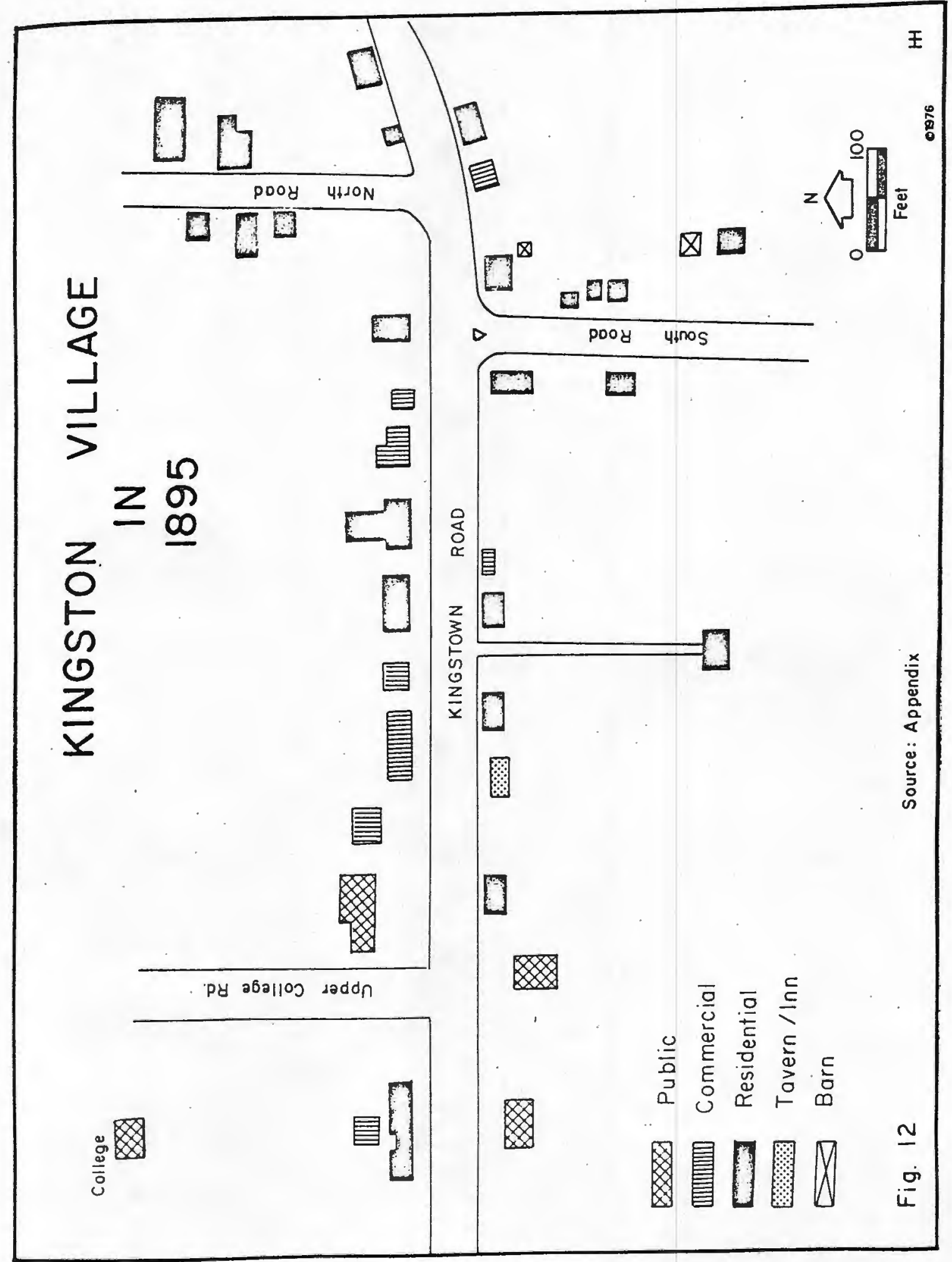


cause of the cessation of growth noted that the decline began with the obsequies of its last inn-keeper and arrived at the logical conclusion that if Little Rest ever expected to regain its pristine glory the first thing to be done was to provide accommodations for visitors other than those who are unwillingly tarrying in the dinky little jail on the brow of the hill. 157

A group of "well to do" men lead by Bernon Helme purchased the Kingston Inn in 1911 in an effort to revive the community. 158 Their efforts however, were more in keeping with the decline rather than a revival. The group erected an apartment addition to the old building which has ever since been used as a student apartment house.

The college grew in enrollments. This in turn resulted in increases in faculty and staff as well as new buildings. In 1890 there were 33 students in the first class, 342 by $1920,7,097$ by 1960 , and by 1974-75 total enrollments reached $11,580.159$

The University of Rhode Island

Early development of the college campus was concentrated between Lower College Road and Upper College Road. Prior to 1900 the first campus buildings formed half a square between these two roads as shown in Figure 13. They were Taft, Davis, and Lippitt Halls, all constructed Archives.

157 "Providence Journal," April 14, 1912, Kingston

158 Ibia.

159University of Rhode Island Bulletins and Catalogs, $1890,1920,1960,1974-75$. 
of granite quarried on Kingston Hill. 160 Between 1900 and 1921 the square or quadrangle formation was complete with the erection of East, Washburn and Ranger Halls. The Memorial Gateway and Grove were dedicated in 1928 as the entrance to the campus. Twenty-nine buildings were errected within a decade between 1960 and 1970.161 These are shown in Figures 13 through 16 and illustrate the growth patterns of the University up to the present time.

Two important events occured which influuenced this growth. On March 23, 1951 the college officially became the University of Rhode Island. ${ }^{162}$ Dr. Carl Woodward served as President of the institution from 1941 to 1958. Dean Harold Browning summarized the accomplishments of $\mathrm{Dr}$. Woodward's administration:

attainment of university status, accreditation of the academic programs, creation of the Engineering Experiment station, the School of Nursing and the College of Pharmacy, introduction of national honor scoieties, construction of the Memorial Union and several other buildings, improved public, relations, success in referenda.. 163

Under Dr. Woodward the landgrant college's "aggie" program continued while growth in other endeavors became impressive.

\footnotetext{
160 Herman Eschenbacher, The University of Rhode Island, p. 180 .

${ }^{16}$ Data gathered from library sources: U.R.I. catalogs, bulletins, manuscripts, Eschenbacher and other sources.

162 Herman Eschenbacher, The University of Rhode Island, p. 348 .

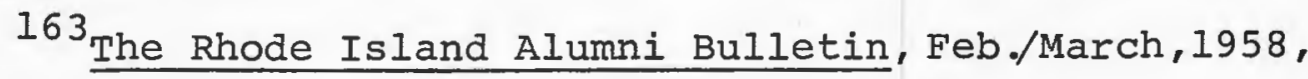
p. 15 .
} 


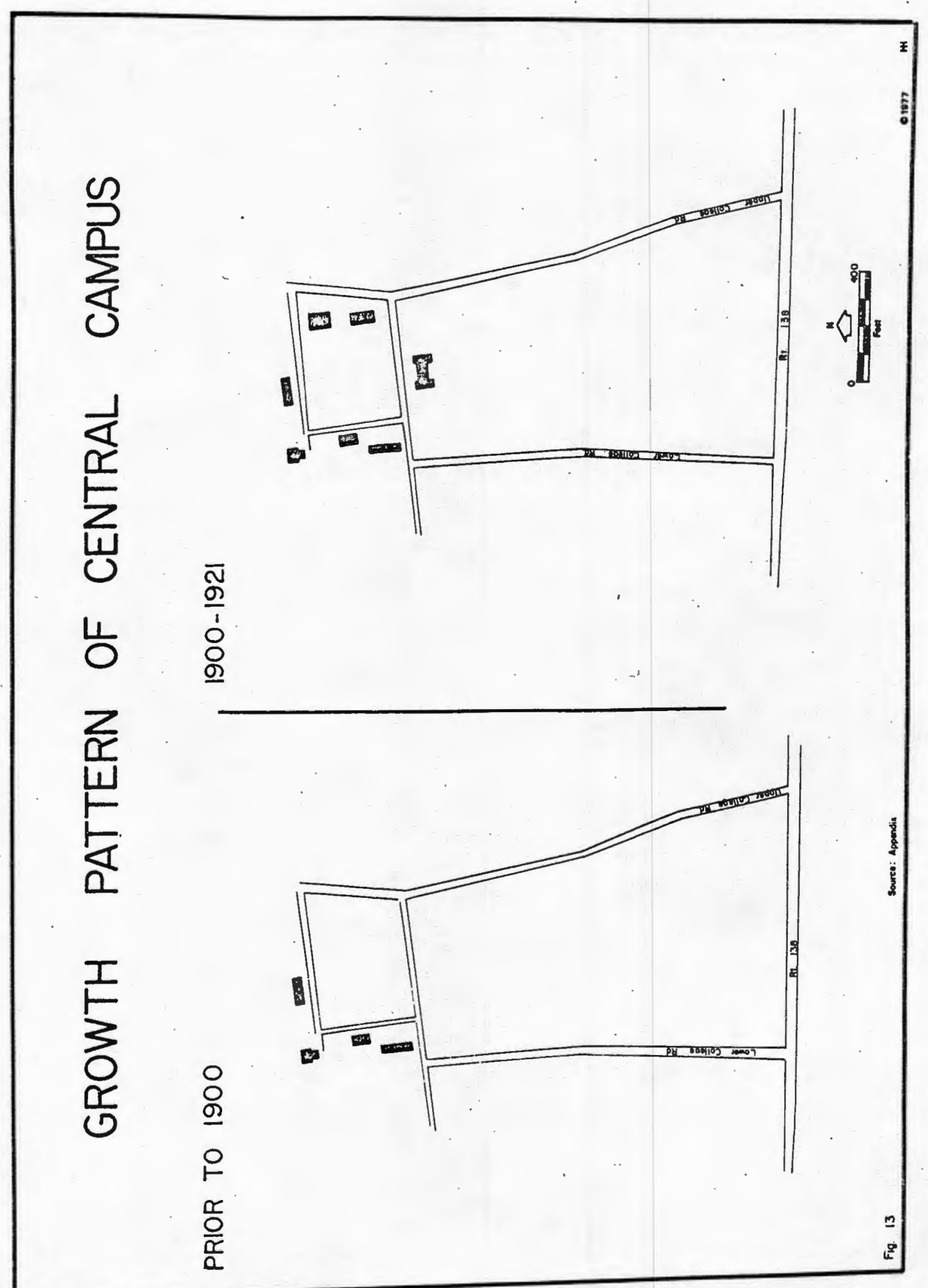




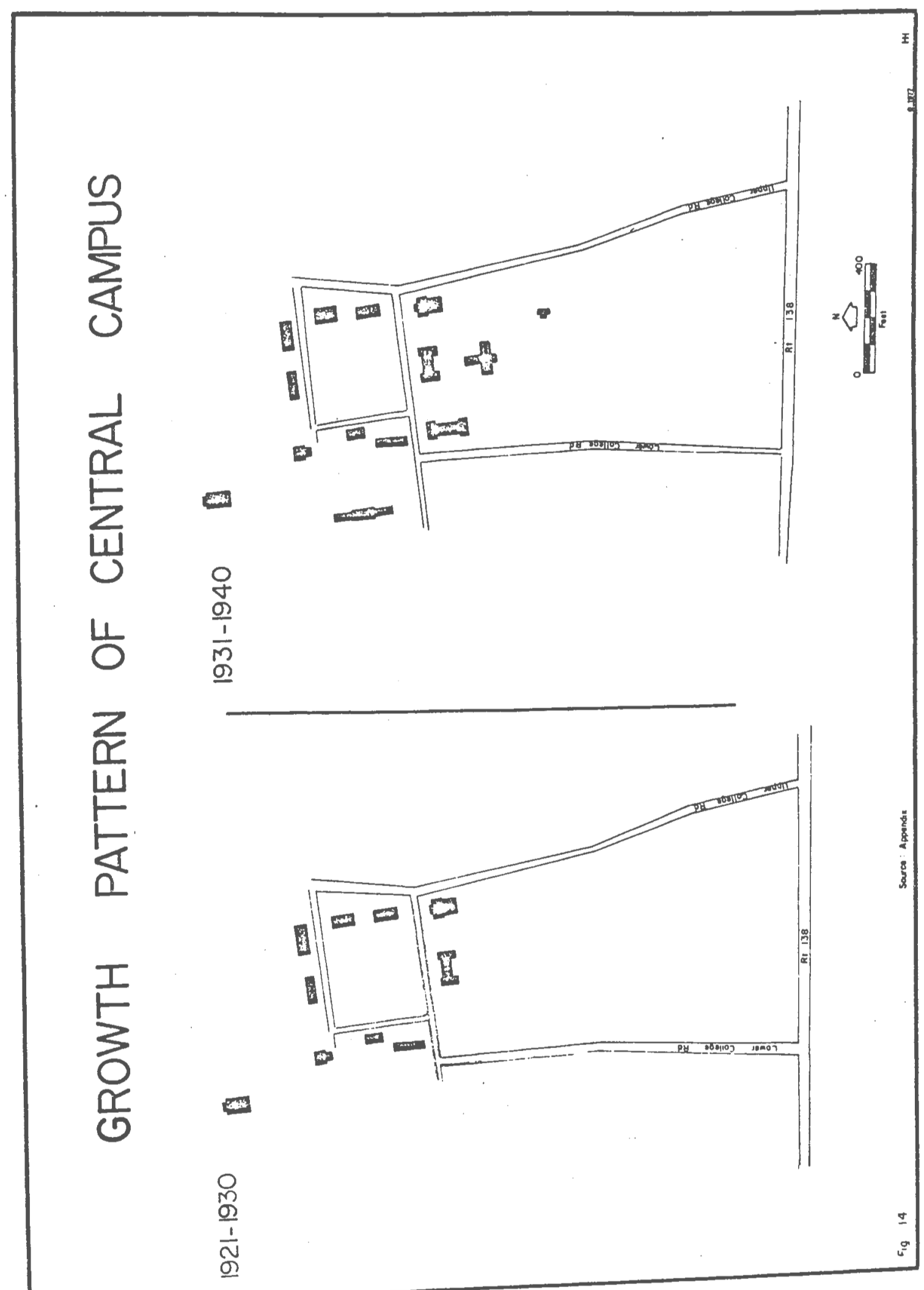




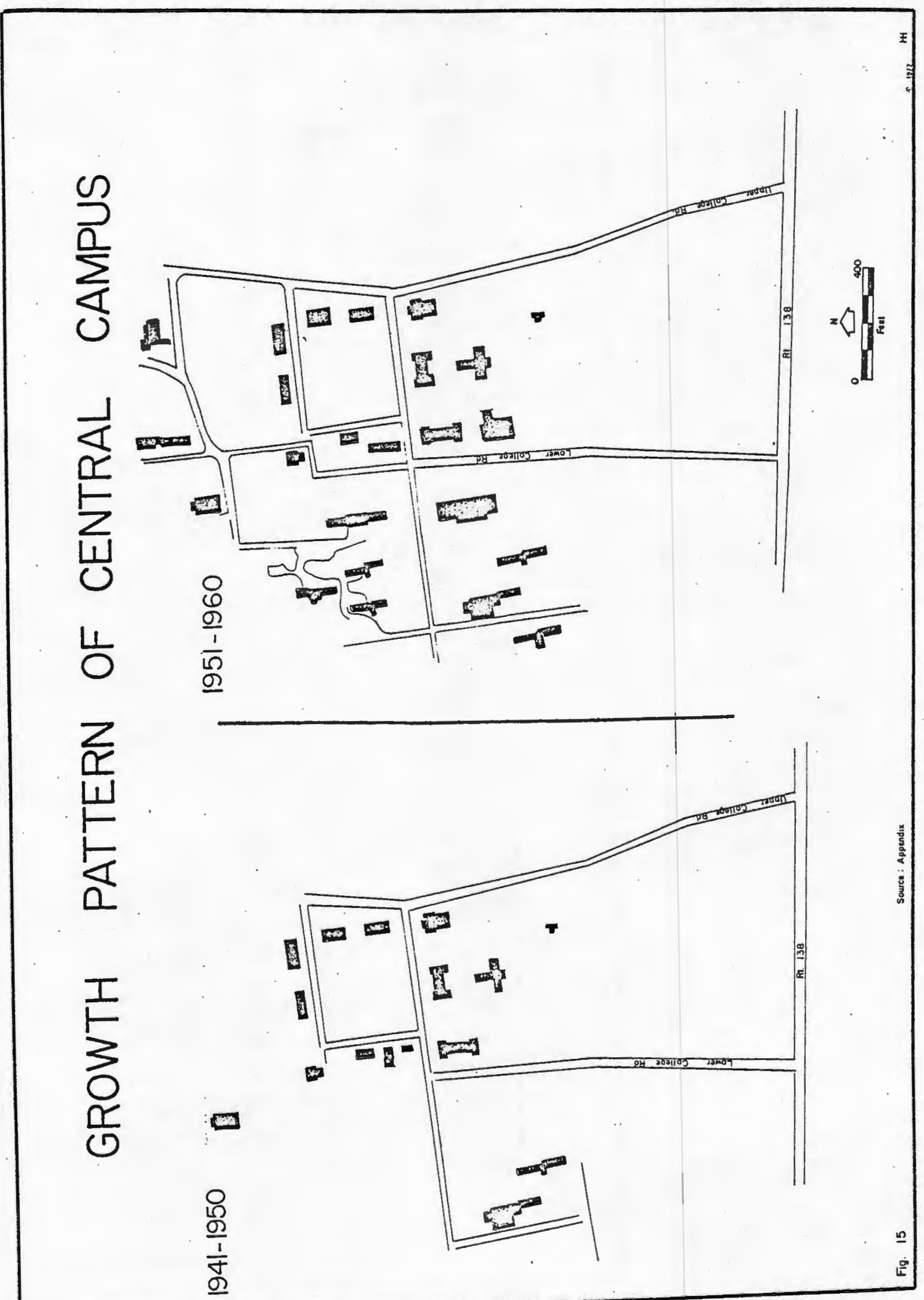




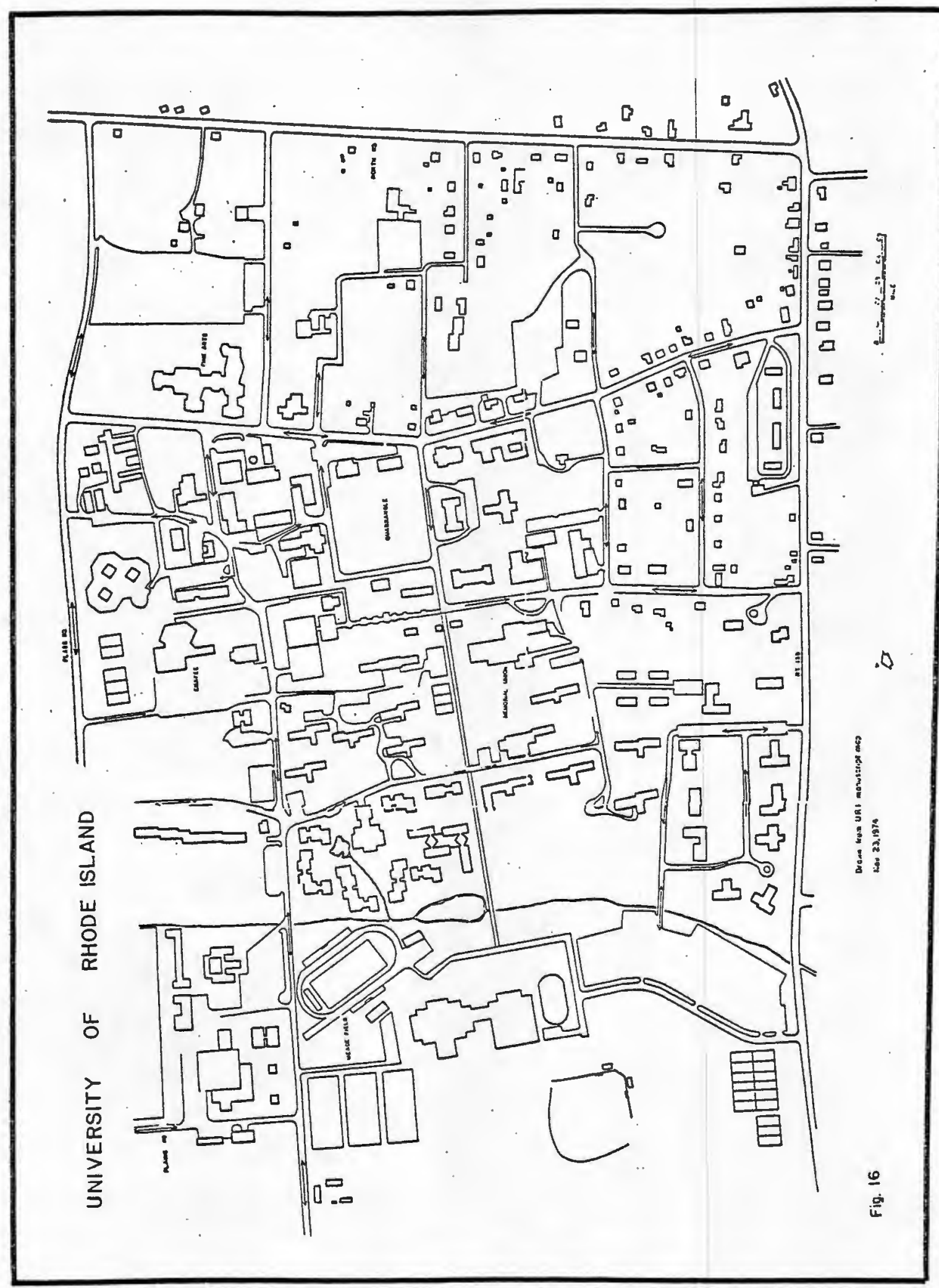


The second important event was the induction of Dr. Francis Horn as successor to Dr. Woodward in 1958. Dr. Horn brought with him a national reputation as a distinguised scholar and administrator. His interests were world wide rather than local or state oriented. Emphasis was placed on the true spirit of a university based on academic excellence and the pursuit of knowledge as well as individual student development. New growth was emphasized by the erection of a new library, a fine arts center, the Narragansett Bay Campus and its new school of oceanography. At the dedication of Horn Laboratory it was said to the then former president:

During your nine years as President, the University doubled its enrollment and $\$ 40,000,000$ in construction was completed; but the Horn heritage is not chiefly buildings. It is the climate of academic freedom with clearly stated bases, a strong faculty government, a graduate school of significant proportions, and the firm groundwork for a vigorous University. 164

Student awareness grew in the 1960's and manifested itself in riots and demonstrations over U.S. federaI policies concerning Viet Nam and civil rights issues. President Lyndon Johnson used a visit to the campus in 1966 as a national forum to state his views. ${ }^{165}$ The tiny agricultural school with 33 students had become a full fledged university and achieved national recognition.

164 "Dedication Booklet for the Horn Laboratory," The Graduate School of Oceanography, Curriculum Announcement, U.R.I., 1972-3.

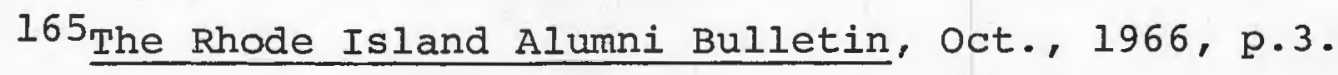


The University and Kingston

In losing the commercial vitality that previously had given it character the old village center became peripheral while the college campus became the community focal point. As functions changed so did the land use of Kingston's core area.

While enrollments and the campus grew so did the need for single family housing for staff and faculty. After World War II a few sub-divisions such as Cherry Road and Clarke Lane on South Road were established between 1955 and 1965. The developments included the area within the village north of main street, South Road, and Biscuit City. A reporter referred to such areas as "faculty ghettos."166 The demands of growth by the University were clearly evident by the change in the morphology of the landscape, not just of the core but the surrounding residential districts as well.

The wider community of the Town of South Kingstown with its commercial core in Wakefield enjoyed strong economic growth as the University in Kingston expanded. In $1960 \mathrm{Dr}$. Niels Rorholm concluded a survey entitled "The University of Rhode Island As An Economic Factor In The Community." He found that $70 \%$ of the total payroll

166 Maury KIein, "Welcome to Megalopolis," The Providence Journal Sunday Rhode Islander Magazine, Nov. 16, 1975, p. 31 . 
expenditures to university employees went to residents of the Town of South Kingstown. ${ }^{167}$ It was also determined that university employees paid real estate taxes averaging $\$ 254$ per individual while local individuals not associated with the school paid taxes averaging $\$ 170$ per person. The study further indicated "that even though working at a tax exempt institution, employees at the University of Rhode Island share fully in carrying the expense of their town."168 He listed three ways in which the University contributes to the economic base of the community: First, the University purchases much of its supplies from large wholesalers but also buys items from local markets. secondly, the tourist season is of a short duration while the University is of a longer duration and each helps to stablilize local economics over the full year period. Thirdly, Dr. Rorholm believed, the University and its research functions will eventually attract more industrial firms to the area.

${ }^{167} \mathrm{Dr}$. Niels Rorholm, "The University of Rhode Island As An Economic Factor In The Community," U.R.I. Archives. 168 Ibid. 


\section{CHAPTER VI \\ KINGSTON TODAY}

Today the village is but a remnant of its past convivial self. It no longer has an active main street of commercial wares and services. The village and its surroundings, as used in this study, can be divided into three functional sectors. The core is designated as the "Historic District" which is located along either side of Route 138 and along North and South Roads. This is shown in Figure 17. This was created by the Town Council in 1960 in accordance with an act of the Rhode Island General Assembly providing for historic zoning. An "Historic District Commission" of seven members is appointed by the Town Council. The purpose of the Commission is to preserve historic structures and limit alterations to their exterior so that they remain as they are for future generations. These buildings are used for private residences, private associations, apartment buildings and for commercial use.

The second sector is the University of Rhode Island, which is the main external influence on the village. Except for the rental of apartment accommodations, and services available at Kingston's two commercial areas in its core the University exists as an enclave. The University has its own union, bookstore, medical services, police, apartments 


\section{KINGSTON STUDY AREA-FUNCTIONAL SECTORS}

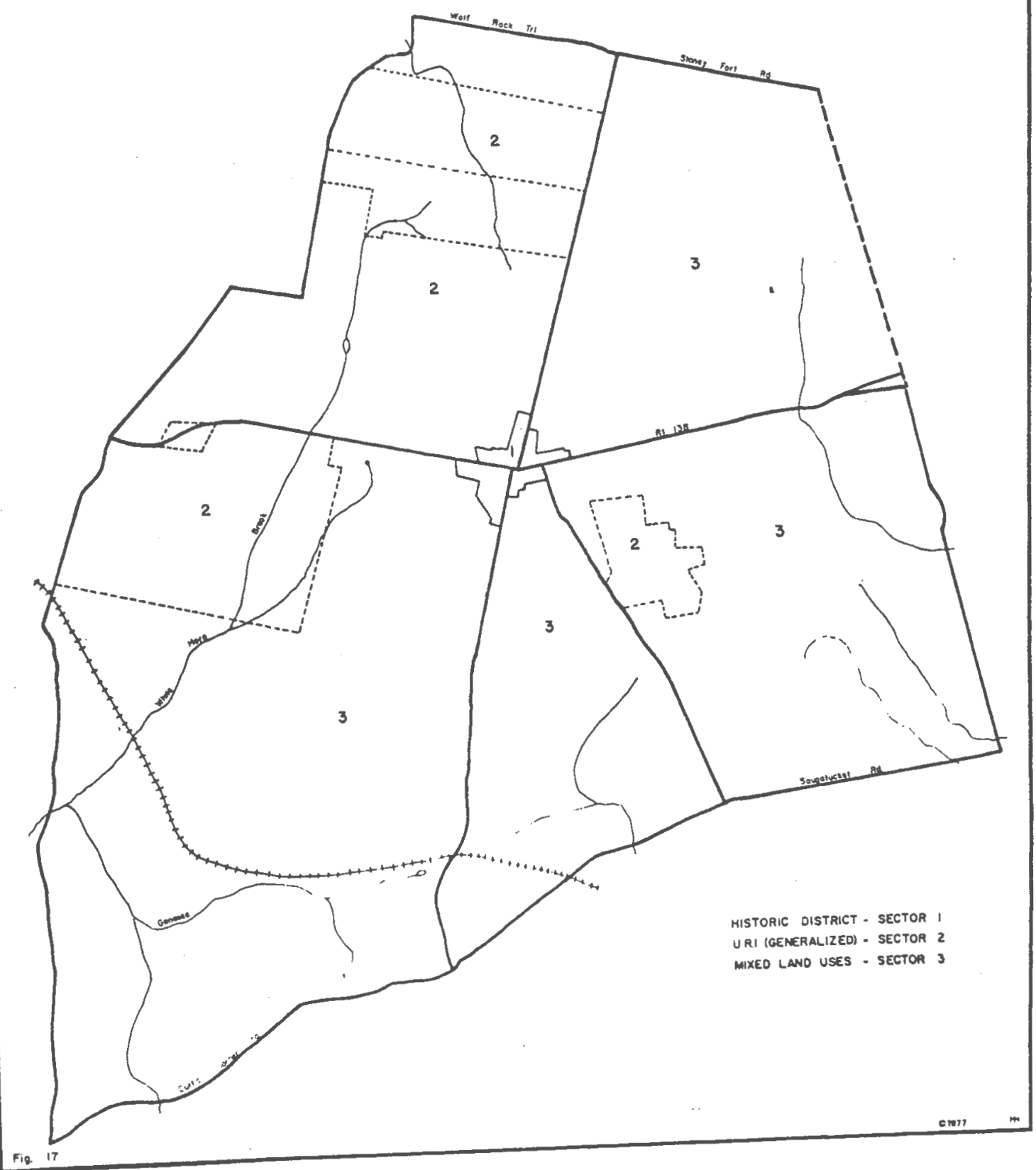


for faculty and graduate students, dormitories, restaurants, and entertainments.

The third sector is the surrounding area of mixed land uses, mainly single family residential but with some multi-family residences and a few commercial establishments.

\section{Present Zoning Pattern of Kingston}

The zoning map of South Kingstown is actually a guide for future development. Zoning designations have to do mainly with density and type of land use. Figure 18 shows the zoning designations of the built up section of Kingston. In general high density "Rl0" or quarter acre lots are located between Kingstown Road, Flagg Road and a small section east of North Road. "Rlo" is defined as,

high-density residential areas with public water. They generally are within the areas which are expected to be served by the sewer system. Selected public and semi-public uses are allowed in these areas.169

However, the highest density designation is not within the direct center of Kingston but to the east of State Route 108. This is allocated as "RM" and defined as,

Residential-Multi-Family District. These are high-density residential zones and areas well serviced by public utilities, services and facilities, in which single family and
multi-family dwellings are allowed. 170

169 "Town of South Kingstown Proposed Zoning Ordinance," Narragansett Times, March 11, 1976, p. 1-C.

${ }^{170}$ Ibid. 
KINGSTON CORE ZONING PATTERN

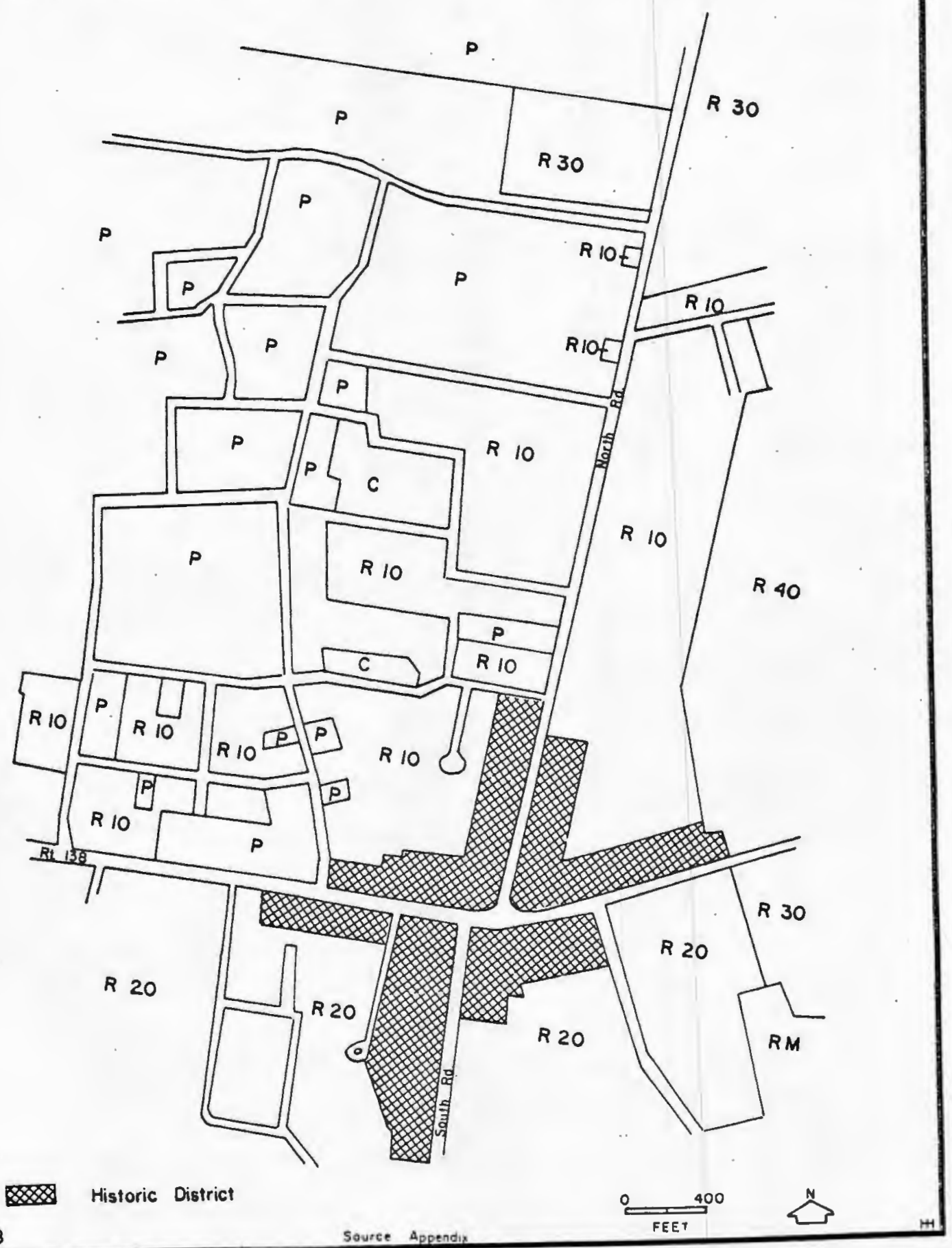

Fig. 18 
To the south of Kingstown Road the land is designated for one-half acre lots or "R20." To the west and north density is dropped to "R30," three-quarter acre lots, and "R40," one acre lots.

The University of Rhode Island property is zoned "Public." It is found in the western section of Kingston's built up area and north of Kingstown Road. It is listed as "Public" because it is state owned land.

There are only two commercial districts listed on the map for Kingston itself. Both are designated for "C2" development. This is defined as,

primarily neighborhood retail areas with specific public and semi-public uses with single and multi-family residential development under special conditions, all of which must meet certain design and site planning
requirements. 171

One such zone is located on Briar Lane and at the present time is comprised of a post office, grocery store and pizza shop. The other "C2" zone is located on Fortin Road and has not been built on.

The zoning designations for the larger study area are shown in Figure 19. They range from the densest of "RM" located along state Route 108 to the lowest along the periphery of "R-R80," two acre lot zoning. Considering the area which surrounds Kingston village, the sector with the highest density is located along state Route 108. It is a 


\section{KINGSTON STUDY AREA ZONES}

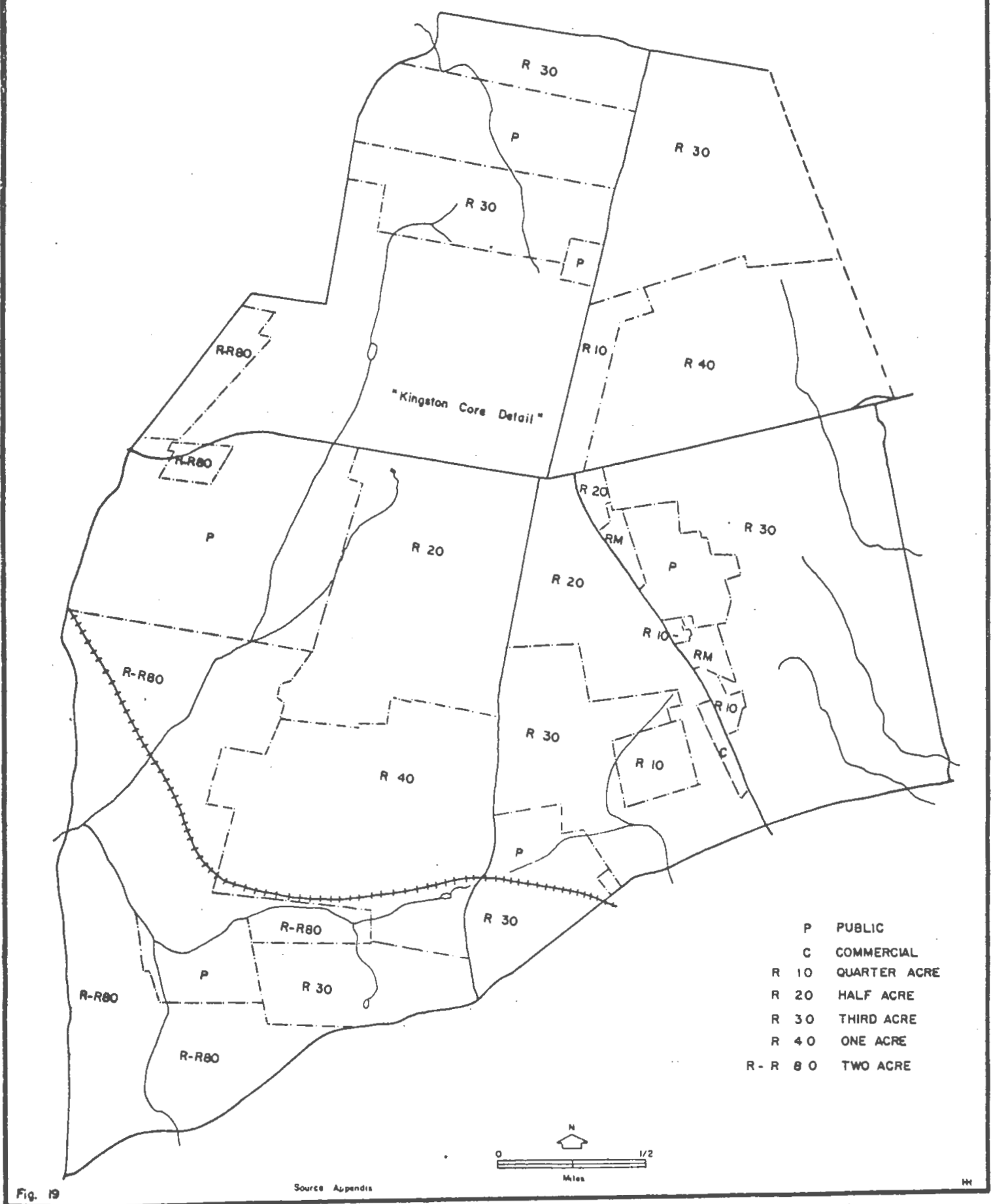


mixture of "RM," "RlO," and "C4," or stated another way as a mixture of quarter acre, multi-family, and commercial zones. The eastern portion of the study area is designated for three quarter and one acre lots. The southern portion is a mixture of one half, three quarter and one acre zones with two zones allocated for two acre sized lots. There is one Public zonal designation. Much of the territory west of the village is listed as Public and in the north there are two three quarter acre lot zones and one Public zone.

It may then be stated that as planned by the above zoning framework for future growth that the study area will be characterized by continued low density. Even the built up area is of relatively low density designations. Its core has only one "RM" zone while the rest are designated single family with the smallest lot size of one quarter acre.

\section{Kingston's Present Land Use Pattern}

The built up section or core of kingston is comprised mainly of single family housing, university activities and two commercial areas as shown in Figure 20. The first commercial sector is located along state Route 138 and is the site of the Kingston Hill store. The other is located at Briar Lane and as previously mentioned contains the post office, grocery store and pizza shop. Remaining open space is in general wooded with some farm uses.

In describing the surrounding study area one immediately notices the large amount of wooded open space. 


\section{KINGSTON STUDY AREA LAND USE}

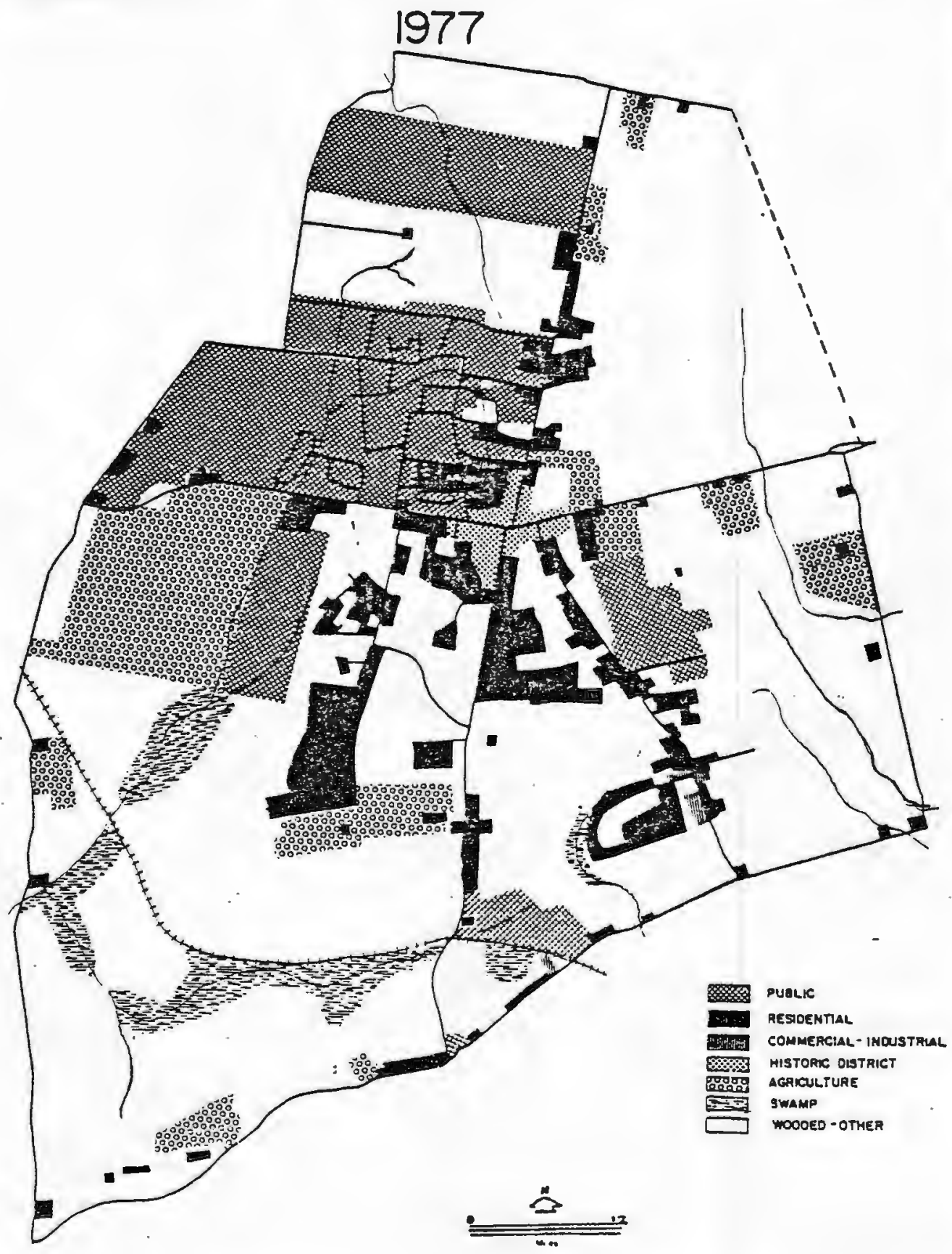

F) 20 
Secondly the University holds considerable area to the west and north as well as a farm to the east of State Route 108.

Kingston's Environmental Problems

Many Kingston residents believe the most serious environmental problem of the community is traffic congestion. There are two forms of traffic movement with which the village must contend. The first is through traffic movement which originates and ends outside of Kingston. As shown in this paper Kingston developed along its main street which became State Route 138, a major east-west link in the Rhode Island transportation network.

The second type of traffic movement through the village is generated locally by the University. According to a traffic survey conducted by the state Department of Transportation the most heavily travelled intersection is at the junction of Route 108 and Route 138.172 The survey was conducted during an average school day in the fall of 1972. The heaviest traffic volume was shown to be along Route 138 between Route 108 and Upper College Road. This type of study provides important information as to the total volume of traffic along links within the road network. However, it is not possible to accurately determine origins and destinations from such data. This information is important if we are to understand Kingston's commuter problem.

172 "Highway Traffic Survey 1974," Rhode Island Department of Transportation. 


\section{Commuters}

Not all of the U.R.I.'s present students have the money or desire to live on campus in a dormitory. Many students commute to the campus each day. When this figure is added to the number of commuting faculty and staff the result is morning and afternoon traffic jams. According to the University campus police, there are 8,000 cars registered by students, faculty and staff while there are only 5,000 parking places on campus.

There being no information available as to the origins of commuters, it was necessary to gather such data for this thesis by using the U.R.I. 1974-75 student directory. Tabulations were made which show that there were 2,832 regular session undergraduate student commuters. They could be separated into two types identified as primary and secondary. A primary commuter commutes from his parents' home while the secondary commuter rents accommodations and commutes from the rented quarters. Primary commuters are scattered all over the state with a large percentage coming from the densely populated urbanized areas of Pawtucket, Providence, Cranston, and Warwick. Secondary commuters are clustered in the beach areas to the south of Kingston particularly in the town of Narragansett. This is shown in Figure 21.

A questionnaire was administered by telephone interview to determine travel habits and attitudes of secondary undergraduate commuters, since these students, having chosen not to live with their parents, could live in kingston if 
U.R.I. COMMUTER PATTERN (UNDERGRADUATE)
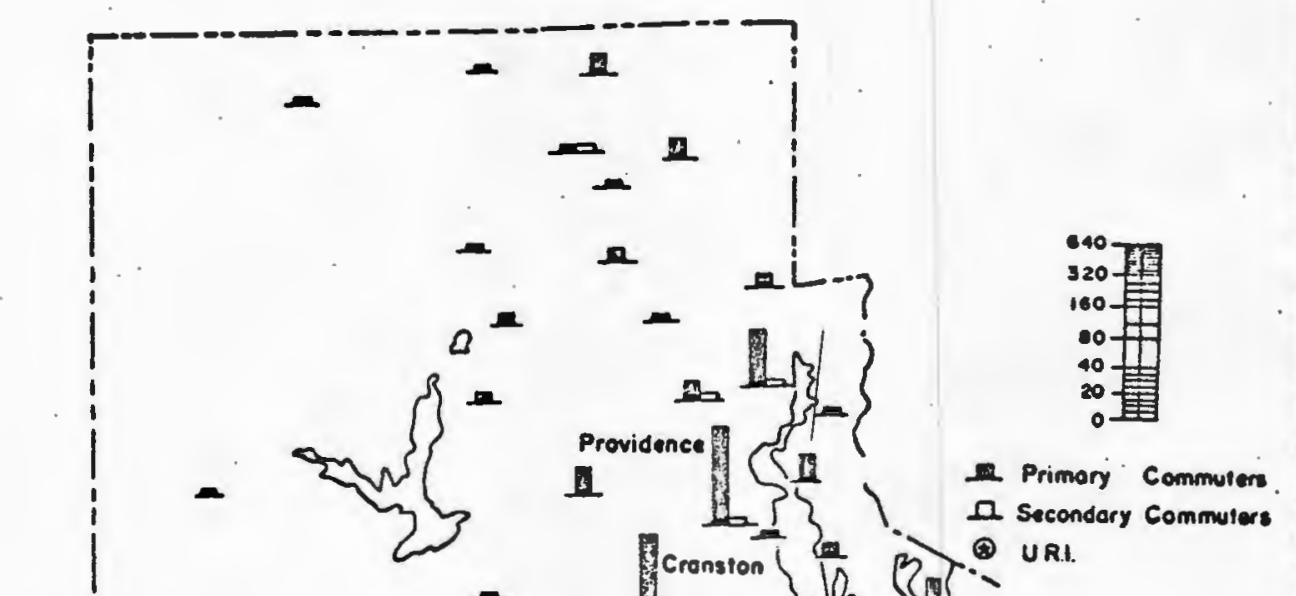

- 1 L<smiles>C1=[Ge]C[Ge]1</smiles>

$\int_{0} \frac{\pi}{2}$

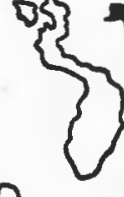

-

n<smiles>C=C1CCCC1C1CC1</smiles>

Groenvich $2<$

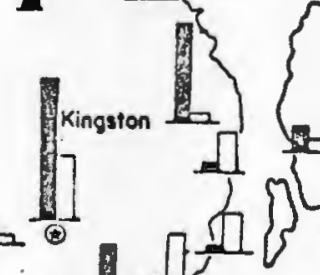

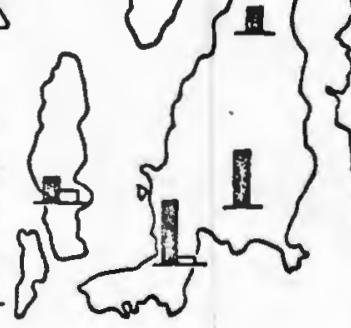

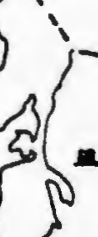


that were feasible. However, they don't choose to live in Kingston and therefore contribute to the traffic problem as commuters.

The survey shows that the majority of secondary commuters overwhelmingly do not want standard dormitory rooms but prefer apartments. They chose their present locations because they were cheaper and near the beach. Most of them drive their own cars. Most students said they would opt for the bus if cheaper student fares were instituted by the bus company. However, many added that the bus wanders all over the countryside and so takes too much time. Some said that bus stops are not convenient to their locations. On the average most commuters said that they make one trip to the campus per day. Seventy percent of the students replied that they would prefer to live in Kingston if similar accommodations were available for approximately the same rent.

In another commuter opinion survey made by two students in 1975 the traffic flow through Kingston to the University arrived and departed 29.7\% along state Route 108 from the South, 23.4\% along North Road from the North, 21.9\% from the East along State Route 138, 20.3\% from the West along State Route 138 and 4.7\% from State Route 110. The survey was designed to sample all commuters whether student, faculty, or staff. However, $71 \%$ of all respondents were faculty and only $25 \%$ were student commuters. Fifty-four percent of the drivers found driving difficult. Forty-three percent 
preferred more inner-campus parking rather than improvements in bus service which were desired by $32 \%$. A majority (57\%) also wanted the University to construct more parking lots and roads. Wesley Ewell, one of the student researchers, stated that, "Commuter preferences lie clearly toward more and better roads."173 It is interesting to note that while an overwhelming majority preferred the auto| and better accommodations for it, $45.4 \%$ desired an unspoiled greenbelt around the village, and another $43.7 \%$ believed that new growth should be consistent with the existing character of the village. It is obvious that there are aiffering opinions and inconsistencies in desired goals.

Parking In The Viliage

Just as the University of Rhode Island traffic flows are tidal corresponding with the time of the school day and the school term so are traffic problems with relation to various churches in the village and with exhibits and sales of the Art Association. Each Sunday morning the Congregational Church is a focal point of congestion at the corner of Route 138 and Upper College Road. The church and its parking lot are on high ground above the road grade. The only entry and exit ways are along Route 138. The combination of these factors makes the situation quite hazardous and contributes to the pile-up and confusion at the light located there. Cars that arrive too late to find a parking spot tend to park

173"The Kingston BY-Pass, A U.R.I. Graduate Seminar in Geography," 1975, p. 7-8. 
up and down Route 138, on Upper College Road, and in other public parking areas such as Potter Hall lot. The same pile-up occurs when the Art Association holds exhibitions and sales. Cars again park on either side of the street, wherever they can find some space.

Potter Hall, Kingston Free Library, which houses public meetings and community events has an inadequate parking lot situated at the intersection of Route 138 and Upper College Road. Cars must park at an angle to the road and when leaving must back out onto the busy road. The Fayerweather craft shop is located at an intersection. It is at the eastern side of the town near the traffic light at the intersection of Route 138 and Route 108. A small parking lot was made in the rear of the yard but the traffic going in and coming out must navigate the oncoming flow and back up of traffic at the light. Some cars park in front of the building or across the road and create a hazardous traffic situation.

Suggested Future Alternatives To Kingston's Traffic Problem

The State Department of Transportation has proposed a new interstate, I-895, which would go to the north of Kingston and connect with the Jamestown Bridge-Newport interchange on Route 1. The firm of wilbur Smith Associates has been employed to research the impact of such a road upon the surrounding area. Some kingston residents believe that this would alleviate the traffic congestion in the village. 
However, a citizen advisory group known as P.A.C., Washington County Project Area Committee, is not in favor of the new interstate proposal. They stated that it would be too costly and might create a "Chinese wall."174

Using the information from both the origin and questionnaire data we might consider Kingston's U.R.I. commuter traffic. The overwhelming choice of secondary commuters is the auto because they regard it as more economical and convenient than the bus. The questions concerning bus transportation received considerable numbers of negative remarks as to what students think of the local bus system. The bus in their opinion is not competitive with gasoline costs. One trip is $35 \xi$ by bus while a gallon of gas is at the present time not that much more. The bus stop is not convenient to the housing locations of Narragansett commuters. The students also complained that the bus wanders a great deal of time travelling all over the countryside before arriving at the campus. Patronage could be encouraged if buses would serve people rather than simply link up prominent intersections. Populations are so dispersed that assembly at specific intersections is often difficult. "Fast buses" to the U.R.I. campus are needed. These direct buses could stop at areas known as high density university oriented commuter populations such as Narragansett, Scarborough, etc. Then the buses could make a return trip late in the afternoon. 
In order to capture this market buses must be economical, convenient and efficient. Students would ride them and traffic congestion would be lessened.

The University could also limit parking facilities within the campus. If there are no places to park then students will find other ways of reaching the campus. Of course some alternate means, such as bus transportation specifically for students, should be implemented if parking were to be cut off. Many on-campus students have cars. These students could be required to leave their cars at home and use bus transportation to off campus activities. Another alternative would be for more apartment dwellings in Kingston. Kingston's rents are more expensive than those in Narragansett, where many commuters live. Seventy percent of those questioned said they would prefer to live in Kingston if they could obtain similar accommodations at the rents they are paying in Narragansett.

If a people approach is not taken by mass transit then people will not patronize it except under duress. The car will stay until there is a better alternative. To relieve congestion and expedite traffic through the village and campus an approach similar to the "London Maze" might be designated. Upper college Road could be made one-way going out of the campus while North Road could be made oneway going into the campus. Plains Road could continue to be both. Another approach might be to situate parking areas in such a way that those who take a less congested route 
might get a better parking spot. Students complained in the telephone interview over parking difficulties.

One of the worst traffic intersections in Kingston is at the junction of State Routes 138 and 108. At one time the state Department of Transportation made the proposal to put a rotary at that intersection. A continual right hand lane could be added to either side of Route 108 (one already exists on the west of the junction but it is in poor shape) that would make the corner less hazardous.

A strip could be left for a bike path from Peace Dale through kingston. It need not be large, just a slight addition to the shoulder marked by yellow paint. This would add to the amenity of the village and give cyclists a chance; today it is a constant fight with the traffic. The designated area could be set off by a yellow line. With the sewer project in process this would be a small added charge. There are no sidewalks between Kingston and Peace Dale which is a relatively short distance. It is in fact a gap in the system which exists in Kingston, Peace Dale and Wakefield. A sidewalk along that stretch of road would add greatly to the area and to the safety of residents.

Several suggestions have been made by the former Town Planner and the State Department of Transportation. Their plan entitled "The Upgrading of Route 138" issued July, 1974, utilizes the widening of main routes 138 and 108 in order that they might continue carrying the bulk of the traffic. A by-pass plan is included. This by-pass is labeled Route B 
on Figure 22 and would trail off of Route 108 and enter the campus north of Flagg Road. An overpass would be located at its juncture with Route 138. In 1965 sasaki Consultants suggested a similar by-pass plan. However their by-pass options travelled along a different path. One option labeled A on Figure 22 followed a fifty foot strip allocated by the owner as a road and a second option, not listed on the figure, went to the east of Route $B$ near the base of Kingston hill. Route $B$ is a part of proposed Route I-895 already discussed in this chapter. Residents do not want a superhighway cutting through the countryside disturbing their environment and quality of life. This route is not necessary since the I-895 connector is located at North Road which could handle the traffic. Economically Route B is an economic "boondoggle". The road would be less than one mile long having a divider strip down the center and topped by an overpass. This type of transportation "overkill" should not be near "Historic Kingston." Route A would be of no help and would only add to the traffic confusion.

Another alternative which would make far more sense with respect to Kingston's road system would be to simply upgrade the already existing roads. The present Town Planner, Mrs. Anna Prager, believes that is the solution. This researcher agrees with her. More emphasis in the future should be placed on mass transit, more accommodations for 


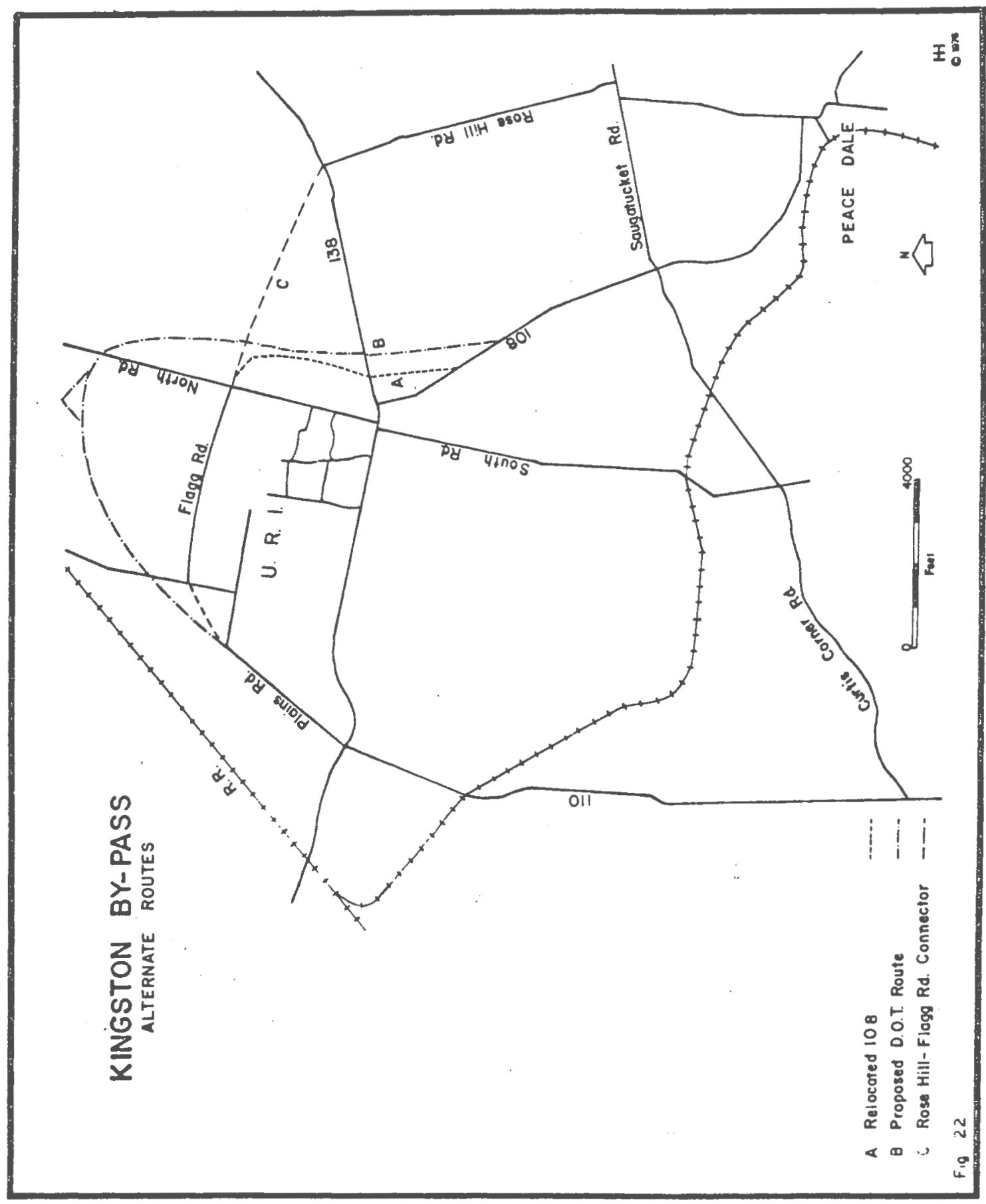


students in Kingston, and a network of bike paths and sidewalks. 
CHAPTER VII

\section{CONCLUSION}

The main hypothesis of this study is that Kingston was settled and evolved the way it did as the result of local initiatives taken by its leading citizens with the support of the community. Entrepreneurial vision, investment and political intrigue were more important than natural resources or geographic location in promoting the community's growth and character.

The physical characteristics of the village site and its surroundings were appraised. Location, topography, hydrology, and soils were all examined from the standpoint of their possible influences upon the selection of Kingston as a village site. While it was found that none of these factors was so poor as to preclude settlement, other sites such as those of West Kingston, Tower Hill, and Peace Dale had certain advantages which Kingston did not. Tower Hill was eventually abandoned. West Kingston grew very little even after it acquired a railroad depot and courthouse. Peace Dale did not evolve prominently until mid-19th century when it became a mill town.

Kingston ridge is approximately 252 feet above sea level. Geologically the ridge is a continuation of a larger formation which loops around to Rose Hill where no 
significant settlement ever took place. The village itself lies astride a natural divide between the watersheds of the Pawcatuck River and the Rhode Island Coastal Basin.

There are numerous water veins in the granite-gneiss bedrock underlying the ridge. These veins were easily penetrated and drawn upon. Shallow wells dug into the subsoil also supplied water abundantly to early settlers. Due to the impermeability of the subsoil the ground water table is high on Kingston Hill. The old village well, situated in the center of town, is approximately on the divide between the two watersheds.

Kingston's geographic "situation" was not must better than its site. Only after roads were constructed, services generated, and accommodations built did it become a nodal village with the possibilities of external connection and support. The natural site did not afford an ocean harbor, or a confluence of navigable rivers which might have enhanced its situation. Thus its favorable ties within the urban fields, first of Newport, secondly of Providence, developed only as Kingston's entrepreneurs took advantage of favorable commercial and political opportunities. The same opportunities were available to other settlements in the region at the same time but they were not perceived nor acted upon with such commitment. Kingston and its immediate environs offer a good example of what Carl Sauer described as a "cultural landscape." 
A cultural landscape according to slauer reflects the characteristics of a people in the way its space is differentiated and in the way its lands are used. By this definition a landscape is social as well as physical in its morphology. The natural terrain, as modified by a people and their culture, confirms to their technologies, ideals, and goals. Kingston's cultural landscape first evolved under the influence of and in support of the goals of the "Entrepreneurial mind" of 17 th century England. The "New World" was exploited for its natural resources and commodities which were in demand in the "Old World." Colonization was promoted for the financial gain of those wealthy investors who could receive grants from the Crown or its assigns.

Rhode Island was part of a crown grant made in 1606 to the Virginia Company of Plymouth. Subsequently its territory was subdivided into smaller grants each of which was confirmed by a purchase from its Indian occupants. Kingston and its vicinity lay within what was called the "Pettaquamscutt Purchase." The purchasers were Englishmen of wealth and influence capable of exploiting and thereby enhancing their own fortunes. The morphology of the landscape changed from that based upon the communal hunter-gatherer culture of the Narragansett Indians to one supporting private enterprise particularly in agriculture, crafts and foreign trade. The Pettaquamscutt purchasers divided their territory into 
large farms or plantations. Roads were laid out in order to facilitate development of interior lands and the transportation of commodities.

If the physical characteristics of the natural site were not the main factors in the selection of Kingston as a place for settlement how, then, did it come into being? In time the junction of North and South Roads, which followed the central spine of Kingston ridge, became a rest stop for weary travellers. Kingston would in all probability have remained an obscure junction had it not been for the entrepreneurial spirit of a few businessmen who schemed to capture the county seat from Tower Hill which until the mid 18th century had been the most successful settlement within the Pettaquamscutt territory.

The acquisition of Tower Hill's courthouse and jail was the successful conclusion of a three-pronged stratagem. First, the Kingstonians deprecated the structures at Tower Hill which, indeed, were in need of repair. Secondly, a few entrepreneurs offered free land at Kingston for the sites of courthouse and jail, also promising that the community would pay for the new structures. Thirdly, it was agreed that three taverns would be constructed to provide spirits and accommodations for legislators, court personnel, and their entourage. After the abduction of the courthouse the cross-roads rest stop at Kingston flourished, becoming an "urban village" with a main street business district. 
In describing Kingston's evolution it was necessary to define the meaning of "village," "central place," and "urban village." N.S. B. Gras regards the village as a "group of people, a social unit, primarily for economic production but also government, religion, and social intercourse." Rugg regards it as a place that provides essential services and functions for a surrounding rural area. It is also defined as an incorporated place with a population of less than one thousand persons.

As a social unit the village is also a central place. Walter Christaller laid the groundwork for many later theories and studies of urbanization when in 1933 he conceived a "Central Place Theory." It is based upon his analyses of the distribution of communities as they had developed on the relatively homogeneous physical landscape of southern Germany. Neither Kingston's terrain nor its social evolution conform to Christaller's criteria. To Christaller the functions of central places are a response to the purchasing power of populations within their radius. A hierarchy of central places thus emerges in his schema with each category both supporting and being supported by communities lower or higher in his hierarchy. Kingston did not grow by such processes of accretion but became a relatively important center in mid-18th century Rhode Island simply by capturing through political intrigue the important governmental functions of a neighboring village. 
Kingston is not located on an homogeneous plain. Its road network did not evolve as the result of any free competition between alternative routes of travel. Also its services did not evolve in response to any discernable distribution pattern of consumer purchasing power in its hinterland. From the beginning it was a satellite of Pettaquamscutt and Newport. Kingston happened to be located at the junction of roads arbitrarily laid out by the Pettaquamscutt purchasers previous to land subdivision and settlement. Once established as a junction point Kingston did function as a market center for its immediate hinterland until it acquired the courthouse. From 1752 until 1854 it was one of five county seats in Rhode Island where the General Assembly met and enacted laws. Such political significance stimulated economic enterprise. Thus until the industrial revolution gathered momentum and valley towns became attractive to South County's entrepreneurs, Kingston remained the principal village in south Kingstown.

By 1776 Kingston had attained the status of an "urban village" according to Douglas McManis' definition. These were villages in which political, economic and professional activities were centered. They were urban yet small and were characterized by the presence of farming on the periphery.

McManis's definition of an urban village appropriately describes Kingston during the century 1752 - 1854 when people throughout the state arrived for sessions of the 
legislature. A business district emerged which offered an array of commodities and services. The center boasted a variety of professional offices and the shops of craftsmen. At this time Newport was the primate center for Rhode Island. It was founded on commerce, particularly the "Triangular Trade." Farms and plantations surrounding Kingston produced farm commodities which were ferried to Newport and from there shipped to the West Indies while manufactured items were carried from Europe to Newport and thence distributed to merchants along Kingston's main street. After the Revolutionary War Newport declined. The industrial revolution began at Slater's mill in Pawtucket; then other textile factories were located in and around Providence. By 1790 Providence had surpassed Newport in population and in economic vitality. The orientation of Rhode Island's economy shifted from Newport's mercantilism to the mills of Providence and other places where waterpower could be generated.

Fortunately for Kingston the Congregational Church which had been established at Tower Hill was removed from there to Kingston where it was stipulated that the minister would also teach school. The school prospered beyond all expectations and new ones were soon constructed. The quality of the schools and the presence of the new church enhanced the quality of the environment as many of the former taverns were phased out. Children of the industrial elite came from all over the state to attend the new private 
boarding schools where both the natural and the social atmosphere were well regarded. Being a hill town Kingston enjoyed clean country air uncontaminated by the slum housing and foul odors of manufacturing towns in the river valleys. The academies enjoyed an enviable reputation for strict decorum and attendance at church on Sunday was obligatory. Local entrepreneurs went into the boarding house business as a logical adjunct to their private schools and prospered.

All went well until a reform movement led to the creation of a state financed public school system. Faced with tax-supported competition Kingston's private academies went out of business and again the town's development came to a halt. It continued to maintain a few commercial retail and service enterprises but the legislature had stopped meeting there in 1854. Then the courthouse was moved to a new granite structure in west Kingston at the end of the 19 th century.

Again, had it not been for entrepreneurial vision and initiative Kingston might have become just another dying hill town. However, as the state's public school system gained momentum and as the Federal government began to grant aid to states for the support of schools of agriculture and the mechanic arts, Kingston put in a bid to be selected as the site for such a school in Rhode Island. Brown University, as a private school, already was drawing federal funds for its agricultural instruction. However, the state's farmers 
wanted not only an agricultural school but an experiment station as well located in a farming district--not in the city of Providence.

For a third time the movers and shakers of Kingston got together, collected money from local residents, and used their still considerable political influence to bring the federally subsidized "College of Agriculture and Mechanic Arts" to their home town. It proved to be a substantial stimulus to the boarding house industry which had slumped with the closing of the private academies. Angry residents of other towns which had also sought the new school referred to the successful Kingstonians as "those capitalists on the hill."

Changes in the Kingston community over time may be viewed as an example of "sequent occupance"l or a succession of cultural change occurring in a single geographic region as technology and social aspirations changed over time. Wellington Jones lists the "operation units" which a researcher might use in preparing a study of sequent occupance. His outline was most helpful in the preparation of this study. Those itemis which he denotes as functions, forms, natural features of site, external connections, past stages in occupance, and future stages are all discussed in this paper. 175

175 Wellington Jones: "Procedures. In Investigating The Human Occupance of a Region;" Annals of the Association of American Geographers, Vol. 24 (1934) p. 73. 
After World War II both the village and its school of agriculture grew rapidly with the College becoming a University in the spring of 1951. The town added subdivisions along South Road such as Cherry Road, Clarke Lane and Linden Drive. The Biscuit City development was inaugurated south of Route 138. Others were created to the east and west of Route 108. Today many students, faculty, and staff live in Kingston, but malny also live in Narragansett or elsewhere as the University grew more rapidly than the town itself could grow. The residents of Kingston in recent years have reversed tradition and now take a stance against development particularly of multifamily dwellings and commercial establishments. In winter rents are cheaper in Narragansett than in Kingston. Many students rent houses near the beach for the school term. Due to the growth of the University and the lack of facilities for them there are tidal movements of commuter traffic along Kingston's main street. According to a commuter survey $70 \%$ would prefer to live in Kingston if the same type of accommodations were available at the same costs. Along with these traffic tides congestion develops in connection with the use of the Kingston Free Library, the Art Association Workshop, the church and other activity centers in the core area of Kingston. To find a parking spot is difficult and often hazardous since not enough provision has been made for parking in proportion to the numbers of users. 
The State Department of Transportation has proposed Interstate 895 which would go to the north of Kingston. This road might ease some of Kingston's congestion. However, many residents oppose this plan. The town planner, Anna Prager, does not support it; as to Kingston's traffic problem she believes that an upgrading of present roads would alleviate the situation. This is also the conclusion of this researcher. More roads are not the answer. More emphasis should be placed on the mass transit system. According to the answers on the telephone interviews many commuters said that they would take the bus if it were economical, efficient and convenient. Sidewalks and bike paths would also give local residents another option to the car.

What will Kingston's future be? It will depend upon the initiative of its residents just as it did in the past. 
APPENDICES 
APPENDIX A

Map Sources 
MAP SOURCES

Figure

1. Large Base Map - "Kingston Quadrangle," "Slocum Quadrangle," and "Narragansett Quadrangle". U. S. Geological Survey, 1970.

Smal1 Base Map - Kupa, John J. and Whitman, William. "Landcover Types of Rhode Island: An Ecological Inventory." University of Rhode Island Agricultural Experiment station Bulletin \# 409 (1972): p. 20.

2. Base Map - "Kingston Quadrangle," U.S. Geological Survey, 1970

Contours - "Tanaka Method" hand drawn.

Tanaka, Kitiro. "The Relief Contour Method of Representing Topography on Maps." Geographical Review 40 (1950): 44-56.

3. Base Map - "Kingston Quadrangle," U.S. Geological Survey, 1970.

Text - Kaye, Clifford A. "Surficial Geology of the Kingston Quadrangle." U.S. Geological Survey Bulletin 1071-I (1960): $55 \mathrm{p}$.

4. Base Map - "Kingston Quadrangle," U.S. Geological Survey, 1970.

Text - Moore, George E. "Bedrock Geology of the Kingston Quadrangle." U.S. Geological Survey Bulletin 1158-E (1964) 21 p.

5. Base Map - "Kingston Quadrangle," U. S. Geological Survey, 1970.

Text - Roberts, R. C., Knoblauch, H. C., Madison, S. V., and Hendrick, V. A. "Soil Survey - Kent and Washington Counties, Rhode Island." U. S. Department of Agriculture, Bureau of Chemistry and Soils \#9. (1934) 52 p.

6. Base Map - "Kingston Quadrangle," U. S. Geological Survey, 1970 .

Text - Bierschenk, William H. "Groundwater Resources of the Kingston Quadrangle." Rhode Island Development Council Geological Bulletin \#9 (1956): 60 p. 
Allen, William B., Hahn, Glenn W., and Tuttle, Curtis R., "Geohydrological Data for the Upper Pawcatuck River Basin, Rhode Island." Rhode Island Water Resources Coordinating Board Geological Bulletin No. 13, (1963) 68 p.

7. Base Map - Hazard, Thomas G. and Isham, Norman M.

"A Map of Old Narragansett Plotted for The Honorable Company of Gentlemen Adventurers."

Text - Cady, John Hutchinson. Rhode Island Boundaries. 1636-1936. Providence: Providence State Planning Board, 1936.

Potter, Elisha Reynolds. The Early History of Narragansett. Providence: Marshall and Brown, 1835 .

A copy of the original pettaquamscutt Purchase survey in the U.R.I. Archives.

8. Base Map - Old Houses In The South County of Rhode Island (Providence: Colonial Dames of Rhode Island 1932.

Text - Miller, William Davis. Ancient Roads in the Pettaquamscutt Purchase, Rhode Island. Providence: Rhode Island Historical Society, 1926.

Potter, Elisha Reynolds. The Early History of Narragansett. Providence: Marshall and Brown, 1835, p. 107 .

9. Base Map - "Kingston Quadrangle," U.S. Geological Survey 1970 .

Text - Soth Kingstown Land Evidence Records. Vol. 6, p. 44 .

Elisha Reynolds Potter, History of Narragansett, p. 291 .

South Kingstown Land Evidence Records, Vol. II, p. 320. South Kingstown Land Evidence Records, Vol. II, p. 1. Carder H. Whaley and Alfred Taylor, "Map of the Town of South Kingstown Washington County Rhode Island," (1933)

James Helme, "A Draft of the Highways as they were laid out by the committee appointed by the Town of South Kingstown, : 1737, Unpublished map in U.R.I. archives. 

10. Base map - "Kingston Quadrangle," U.S. Geological
Survey, 1970.

Text - Miller, William Davis. The Narragansett Planters. New York: American Antiquarina Society, 1933.

Well, Rev. Hagadorn. Reminiscences of Little Rest. Unpublished manuscript.

Providence Journal, 1910.

Walling Map, 1833.

11. Base Map - "Kingston Quadrangle," U.S. Geologic Survey, 1970.

Text - Taylor, Philip Kittredge. "Little Rest". The New Ingland Magazine, Vol. XXVIII, No. 2 (April 1903): 129-143.

Walling Map. 1333.

Miss Anstis, Reminiscences of the Village, Unpublished manuscript in Little Rest archives.

Atlas of The State of Rhode Island and Providence Plantations, 1870, "Kingston Inset" p. 115 .

12. Base Map -. "Kingston Quadrangle," U.S. Geologic Survey 1970.

Text - Second Annual Report of the Managers of The Rhode Island State Argicultural School and Experiment Station, Jan. Session, 1890 .

Old Atlas, Kingston insert, 1900, Just a sheet in archives.

13,14,15. Base Map - University of Rhode Island Transportation map. No information but traffic flow.

Text - University of Rhode Island Bulletins and Catalogs for the appropriate years. These were then charted.

16. Base Map - A University of Rhode Island drawn map.

17. Base Map - "Kingston Quadrangle," Geologic Survey, 1970.

Text - Field observation

13. Base Map - "South Kingstown Zoning Orddinance," Narragansett Times, March 4, 1976, p. 160.

Text - same source. 
19. Base Map - "Kingston Quadrangle," Geologic Survey, 1970. Text - "South Kingstown Zoning Ordinance, "Narragansett Times, March 4, 1976, p. 15C

20. Base Map - "Kingston Quadrangle," U.S. Geologic Survey, 1970.

Text - Field Observation.

21. Base Map - Rhode Island Economic Development map, "Those Island."

Text - Questionnaire 
APPENDIX B

Questionnaire Data 
RESULT OF QUESTIONNAIRE

A sample of 118 sùtdents, 12\% sample -- 992

secondary commuters was chosen using the random number technique. There are 14 non-responses equalling $11 \%$ while the total response was $88 \%$. All students questionned are undergraduate secondary commuters. The following percentages are for the total students (104) who did respond.

\section{QUESTIONS}

1. Did you apply for a dormitory room this year?

$$
\begin{aligned}
& \text { Yes }=1 \% \\
& \text { No }=99 \%
\end{aligned}
$$

2. Does it bother you to commute?

$$
\begin{aligned}
& \text { Yes }=14 \% \\
& \text { No }=86 \%
\end{aligned}
$$

3. How do you get to the U.R.I. campus?

$$
\begin{aligned}
& \text { Car }=87 \% \\
& \text { Friend = 9\% } \\
& \text { Bus = 3\% } \\
& \text { Hitch = 1\% }
\end{aligned}
$$

4. Would you take the bus to U.R.I. if you could get a cheap student fare, for instance $\$ 1.00$ for a week's pass to use as often as you wish?

$$
\begin{aligned}
& \text { Yes }=79 \% \\
& \text { No }=21 \%
\end{aligned}
$$

5. Would you take the bus if it were free?

$$
\begin{aligned}
& \text { Yes }=82 \% \\
& \text { No }=18 \%
\end{aligned}
$$

6. What do you estimate are your weekly transportation expenses including gas, car depreciation, maintenance and insurance?

Do not have care $=4 \%$

Replied $\$ 5.00$ or less $=10 \%$

Replied $\$ 6-\$ 10.00=51 \%$

Replied $\$ 15.00=16 \%$

Replied more than $\$ 15.00=19 \%$ 
7. On the average how often do you come to the campus each week?

$$
\begin{aligned}
& 1-4 \text { trips }=24 \% \\
& 5 \text { trips }=50 \% \\
& 6-8 \text { trips }=22 \% \\
& \text { over } 8 \text { trips }=4 \%
\end{aligned}
$$

8. On the average how often do you come to the campus each day?

$$
\begin{aligned}
& 1 \text { trip }=77 \% \\
& 2 \text { trips }=21 \% \\
& \text { Over } 2 \text { trips }=2 \%
\end{aligned}
$$

9. Why did you pick your present housing location?

It was cheaper $=45 \%$

Preferred it $=30 \%$

Couldn't find anything closer to U.R.I. $=3 \%$

For personal reasons $=22 \%$

10. If you could rent similar accommodations in kingston for the same rent and expenses you are now paying would you prefer to live in kingston or where you are now?

Prefer Kingston $=70 \%$

Prefer own location $=30 \%$ 


\section{APPENDIX C}

Selected Bibliography 
Allen, W., Hahn, G. and Tuttle, C. "Geohydrological Data for the Upper Pawcatuck River Basin." Rhode Island Water Resources Bulletin \#13 (1963).

Bacon, Edmund. Design of Cities. New York: Viking Press 1967 .

Bartlett. Records of The Colony of Rhode Island. Vol. III, IV, v; Providence: Knowles, Anthony \& Co., 1360.

Beard, Charles and Mary. The Beard's Basic History of: The United States. New York: Doubleday, Doran \& Co., 1944.

Bierschank, William. "Groundwater Resources of the Kingston Quadrangle." Rhode Island Development Council Geological Bulletin \#9 (1956).

Bowman, Isaiah. "Geographical Interpretation," Geographical Review. 39 (1949): 355-370.

Bridenbaugh, Carl. Cities In Revolt. New York: Knopf, 1955.

"Burgess Interview." Unpublished manuscript in U.R.I. Archives.

Cady, John Hutchinson. Rhode Island Boundaries, 1636-1936. Providence: Providence state Planning Board, 1936.

Christaller, walter. Central Places in Southern Germany. New York: Prentice Hall, 1966.

Eschenbacher, Herman. The University of Rhode Island. New York: Meredith Publishing Co., 1970.

Female Seminary and Family school For Boys. Old catalog in the Kingston Library Archives, Dec. 21, 1854.

Gottmann, Jean. Megalopolis. Cambridge: M.I.T. Press, 1961.

Gras, N.S.B. An Introduction To Economic History. New York: Harper Bros., 1922

Grieve, Robert. The Sea Trade and Its development In Rhode Island and Providence Plantations. Providence: 1902.

Hart, John Fraser, Salisbury, Neil and Smith Everett. "The Dying Village and Some Notions About Urban Growth." Economic Geographer. XIIV (Oct. 1968): 343-349.

Hartshorne, Richard. "The Nature of Geography." Annals of the Association of American Geographers 29, Nos. 3 and 4 (1939). 
Helme, James. A Plat of the Land of Captain Henry Bull. Providence: Society of Colonial Wars, 1926 .

Historic Buildings of South County. Kingston: Pettaquamscutt Historical Society, 1974.

James, Sidney. Colonial Rhode Island-A History. New York: Charles Scribner's \& Sons, 1975.

Jefferson, Mark. "The Distribution of the World's City Folks: A Study in Comparative Civilization." Geographical Review 21 (July 1931): 159-173.

Jones, Emrys. Towns and Cities. London: Oxford University Press, $19 \overline{66 .}$

Jones, Wellington D. "Procedures in Investigating the Human Occupance of a Region." Annals of the Association of American Geographers 24 (1934).

Kaye, Clifford. "Surficial Geology of the Kingston Quadrangle." Rhode Island Geological Survey Bulletin 1071-1: washington D.C., U.S. Printing Office, 1960.

Kingston Academy Catalogue of the Trustees, Instructors and Students. Kingston: Kingston Academy, 1833.

"Kingston's Historic Landowners Bank." Providence Sunday Journal, March 27, 1904.

Klein, Maury. "Welcome to Megalopolis." The Providence Journal Sunday Rhode Islander Magazine (Nov. 16, 1975).

Miller, William Davis. Ancient Roads in the Pettagquamscutt Purchase, Rhode Is land. Providence: Rhode Island Historical Society, 1931.

Miller, William Davis. The Removal of the County Seat From Tower Hill to Kingston. Providence: Rhode Island Historical Society, 1926.

Miller, William Davis. The Narragansett Planters. New York: American Antiquarian Society, 1933.

Narragansett Times, Feb. 15, 1889.

Narragansett Times, Feb. 22, 1889.

Narragansett Times, April 14, 1977. 
North Kingstown Land Records, Vo. 2.

Notestein, Wallace. The English People On The Eve of Colonization 1609-1630. New York: Harper \& Bros.. 1954 .

Philbrick, A. K. A Unit Area Method of Mapping Gross LandUse Associations in Urban Regions. Quoted in Robert S. Platt, Field Study in American Geography, p. 295. Chicago: University of Chicago, 1959.

Philbrick, A. K. Principles of Areal Functional Organization In Regional Human Geography. Quoted in Robert $S$. Platt, Field Study In American Geography p. 338. Chicago: University of Chicago, 1959.

Platt, Robert. Field Study In American Geography. Chicago: University of Chicago, 1959.

Potter, Elisha reynolds. The Early History of Narragansett. Providence: Marshali and Brown, 1835.

Raisz, Erwin. General Cartography. New York: McGraw-Hill, 1948 .

Raisz, Erwin. Principles of Cartography. New York: McGrawHill, 1962 .

Reps, John. The Making of Urban America, A History of City Planning in the United States. Princeton: Princeton University Press, 1965.

Rowse, A. I. The Elizabethans And America. New York: Harper \& Bros, 1959.

Rugg, Dean. Spatial Foundations of Urbanism. Iowa: Wm. C. Brown, 1972.

Sauer, Carl. "The Morphology of Iandscape." Geography II California: University of California Press, 1925: 19-53.

Semple, R. K. and Colledge, R. G. "An Analysis of Entropy Changes in a Settlement Pattern Over Time." Economic Geographer XIVI (1970): 157-160.

Wells, Rev. Hagadorn. Reminiscences of Little Rest. Unpublished manuscript in Kingston Library Archives.

Updike, Wilkins. The History of the Episcopal Church in Narragansett Rhode Island. New York: Henry onderdonk, 1847. 
Whittlesey, Derwent. "Sequent Occupance." Annals of the Association of American Geographers 19 (1929): 162-165.

Woodward, Car. "Kingston's Cultural Heritage." The Rhode Island Yearbook (1970): 58-63. 